\title{
Close Encounters of Lymphoid Cells and Bacteria
}

\author{
Aranzazu Cruz-Adalia* and Esteban Veiga* \\ Department of Molecular and Cellular Biology, Centro Nacional de Biotecnología, Consejo Superior de Investigaciones, \\ Científicas (CNB-CSIC), Madrid, Spain
}

\section{OPEN ACCESS}

Edited by: Abhay Satoskar,

Ohio State University, USA

Reviewed by:

Paul Fisch,

University Medical Center

Freiburg, Germany

Danuta Radzioch,

McGill University, Canada

*Correspondence:

Aranzazu Cruz-Adalia acruz@cnb.csic.es;

Esteban Veiga eveiga@cnb.csic.es

Specialty section:

This article was submitted to Microbial Immunology,

a section of the journal

Frontiers in Immunology

Received: 28 April 2016 Accepted: 21 September 2016

Published: 07 October 2016

Citation:

Cruz-Adalia A and Veiga E (2016) Close Encounters of Lymphoid Cells and Bacteria.

Front. Immunol. 7:405. doi: 10.3389/fimmu.2016.00405
During infections, the first reaction of the host against microbial pathogens is carried out by innate immune cells, which recognize conserved structures on pathogens, called pathogen-associated molecular patterns. Afterward, some of these innate cells can phagocytose and destroy the pathogens, secreting cytokines that would modulate the immune response to the challenge. This rapid response is normally followed by the adaptive immunity, more specific and essential for a complete pathogen clearance in many cases. Some innate immune cells, usually named antigen-presenting cells, such as macrophages or dendritic cells, are able to process internalized invaders and present their antigens to lymphocytes, triggering the adaptive immune response. Nevertheless, the traditional boundary of separated roles between innate and adaptive immunity has been blurred by several studies, showing that very specialized populations of lymphocytes (cells of the adaptive immunity) behave similarly to cells of the innate immunity. These "innate-like" lymphocytes include $\gamma \delta T$ cells, invariant NKT cells, B-1 cells, mucosal-associated invariant $\mathrm{T}$ cells, marginal zone $\mathrm{B}$ cells, and innate response activator cells, and together with the newly described innate lymphoid cells are able to rapidly respond to bacterial infections. Strikingly, our recent data suggest that conventional $\mathrm{CD}^{+} \mathrm{T}$ cells, the paradigm of cells of the adaptive immunity, also present innate-like behavior, capturing bacteria in a process called transinfection. Transinfected CD4+ $\mathrm{T}$ cells digest internalized bacteria like professional phagocytes and secrete large amounts of proinflammatory cytokines, protecting for further bacterial challenges. In the present review, we will focus on the data showing such innate-like behavior of lymphocytes following bacteria encounter.

Keywords: innate-like lymphocytes, conventional T cells, unconventional T cells, gamma delta T cells, B cells, bacteria-lymphocyte interactions

\section{INTRODUCTION}

Classically, the immune system is classified into innate and adaptive immunity. During pathogen challenges, the first host defense involves the innate immune system that provides an immediate response. Innate immune systems are widely spread in nature and can be found in all plants and animals (1). Cells of the innate immune system include mast cells, eosinophils, basophils, natural killers (NKs), and phagocytes [macrophages, neutrophils, and dendritic cells (DCs)]. These cells recognize conserved structures, shared by different pathogens, called pathogen-associated molecular patterns (PAMPs) by their pattern-recognition receptors (PRRs). Afterward, they eliminate pathogens, either by combating through contact or by engulfing them. Some of these 
phagocytes are also antigen-presenting cells (APCs), such as DCs, and after engulfment pathogens, they are able to process and present the invader antigens to activate the cells of the adaptive immunity, the lymphocytes. Albeit both innate and adaptive immunity can distinguish between self and non-self molecules, adaptive immunity is defined by its capacity to specifically recognize a large amount of different antigens, defined by any non-self substance that can be recognized by the immune system. Theoretically, more than $10^{13}$ different antigens could be recognized by the adaptive immunity (2). This highly specific adaptive response takes more time to occur and generates memory, i.e., a second exposition to the same antigen results in faster and more potent response.

$\mathrm{B}$ and $\mathrm{T}$ cells are the major types of lymphocytes within the adaptive response and need to be activated by professional APCs during the antigen presentation. Regarding $\mathrm{T}$ cell activation, processed antigens are presented into the major histocompatibility complex (MHC) molecules on the membrane of APCs. There are two main subtypes of T cells: helper T cells $\left(\mathrm{CD} 4^{+}\right)$and cytotoxic $\mathrm{T}$ cells $\left(\mathrm{CD}^{+}\right)$. Activation of $\mathrm{CD} 4^{+} \mathrm{T}$ cells occurs by the recognition of antigens coupled to class II MHC molecules (MHC-II) by $\mathrm{T}$ cell receptor (TCR). Typically, MHC-II molecules expose antigens degraded into lysosomal compartments (i.e., "foreign" antigens). On the other hand, $\mathrm{CD}^{+} \mathrm{T}$ cells are activated by the detection of antigens coupled to class I MHC (MHC-I). MHC-I molecules present antigens from the cytoplasm (i.e., self-antigens, or viral antigens), but DCs, are also able to present foreign antigens, degraded the lysosome, in their MHC-I by a process called cross-presentation, which is of the major relevance in antibacterial and antitumor fight. B cells express B cell receptors (BCRs) that recognize soluble molecules from pathogens with no need for antigen processing. It has been shown, however, that B cell activation requires presentation by professional APCs in vivo (3). This presentation does not require $\mathrm{MHC}$ molecules.

Antigen presentation by APCs triggers activation and differentiation of naïve lymphocytes to effector cells. B cells suffer immunoglobulin isotype switching and somatic hypermutation, which increase the affinity of the antibodies, and T cells develop distinct effector functions (for example, the secretion of a different array of cytokines or cytolytic activity). This textbook view of the innate and adaptive immunity role separation is being blurred by the discovery of lymphoid cells behaving in an innate-like manner $(4,5)$. Similarly, there exists an increasing body of evidences showing that cells of the innate immunity present adaptive-like behavior developing memory-like characteristics, termed "trained immunity." Trained monocytes respond more efficiently to a second exposition of the same (and different) challenges (6).

In this review, we will focus on the innate-like role of lymphoid cells. These innate-like lymphocytes include specialized populations of lymphocytes, i.e., unconventional $(\gamma \delta) \mathrm{T}$ cells, invariant NKT cells (iNKT), mucosal-associated invariant T (MAIT) cells, B-1 cells, marginal zone (MZ) B cells, innate response activator (IRA) B cells, and the innate lymphoid cells (ILCs) (4). Surprisingly, we have recently shown that conventional $\alpha \beta \mathrm{CD}^{+}$ $\mathrm{T}$ cells, paradigm of adaptive immune cells, are able to capture bacteria from DCs in a process called transinfection and contribute to the early immune response (7). Here, we discuss in some detail the innate-like functions performed by different types of lymphocytes during bacteria encounter.

\section{$\boldsymbol{\gamma} \boldsymbol{\delta} \mathrm{T}$ Cells}

These $\mathrm{T}$ cells, expressing the unconventional $\gamma \delta \mathrm{TCR}$, were discovered from the accidental identification of the TCR $\gamma$ chain (8). $\gamma \delta$ TCRs and $\alpha \beta$ TCRs have qualitatively distinct modes of antigen recognition; $\gamma \delta$ TCRs are not restricted to the recognition of peptides bound to MHC molecules (9). Unlike conventional $\alpha \beta$ T cells, cytokine stimulation, or bacterial contact, is sufficient for activation $\gamma \delta$ T cells, making these cells rapid and potent mediators of inflammation.

They are much less abundant than classical $\alpha \beta$ T cells (1-4\%) in thymus and lymphoid organs of adult mice, but they are in highest abundance in mucosal sites, being $\sim 20-40 \%$ of the intestinal intraepithelial T cells, $\sim 10-20 \%$ of total T cells in the reproductive tracks, and $\sim 50-70 \%$ of skin dermal T cells (10).

In humans, the population of peripheral blood $\gamma \delta \mathrm{T}$ cells is increased in response to infections (11). Initial characterization of human $\gamma \delta$ T cells suggested that antigens recognized by $\gamma \delta$ $\mathrm{T}$ cells were small, non-peptide compounds that contained critical phosphate residues (12). The mainstream $\gamma \delta \mathrm{T}$ cells in human peripheral blood express the TCR V $\gamma 9 \mathrm{~V} \delta 2$, and they can recognize (E)-4-hydroxy-3-methyl-but-2enyl pyrophosphate (HMBPP), which are usually referred as phosphoantigens, derived from various bacteria (13). Moreover, human $\mathrm{V} \gamma 2 \mathrm{~V} \delta 2^{+}$ $\mathrm{T}$ cells can expand 2- to 10 -fold during infections and recognize primary alkylamines derived from microbes, releasing interleukine-2 (IL-2) (14). Lysates or culture supernatants from many bacteria (including mycobacteria, other Gram-negative and Gram-positive cocci, protozoal parasites, and even plants extracts) stimulate $\mathrm{V} \gamma 2 \mathrm{~V} \delta 2^{+} \mathrm{T}$ cells (15). Thus, human peripheral blood $\gamma \delta$ T cells can respond to specific antigens from bacteria [e.g., Mycobacterium tuberculosis (16) and Listeria monocytogenes (17)]. Non-peptidic mycobacterial ligands in human $\mathrm{V} \gamma 9 \mathrm{~V} \delta 2^{+}$ $\mathrm{T}$ cells induce massive tumor necrosis factor (TNF) production (18). Moreover, $\mathrm{V} \gamma 2 \mathrm{~V} \delta 2^{+} \mathrm{T}$ cells respond to non-peptide bacterial antigens predominantly producing Th1 cytokines such as interferon- $\gamma($ IFN- $\gamma)$, although few of them $(<5 \%)$ also produce IL-4 (15). It has been reported that Helicobacter pylori can directly interact with human peripheral $\gamma \delta \mathrm{T}$ cells in vitro, upregulating the activation molecule CD69, TNF- $\alpha$, IFN- $\gamma$, and chemokines, such as MIP-1 $\beta$ and RANTES, favoring an inflammatory environment (19).

In mice, $\gamma \delta \mathrm{T}$ cells expand dramatically after challenge with Mycobacteria, Listeria, and Salmonella spp. (20-22), rapidly producing cytokines. They are able to produce IFN- $\gamma$ after L. monocytogenes infection and IL-4 in response to Nippostrongylus brasiliensis (23). Moreover, it has also been reported that $\gamma \delta$ $\mathrm{T}$ cells are the major IL-17 producers during infections $(24,25)$.

\section{Toll-Like Receptors in $\gamma \delta$ T Cells}

Recognition of bacterial PAMPs by innate immune cells is driven mainly by TLRs, a type of PRRs that recognize bacterial patterns including peptidoglycan and bacterial lipopeptides (TLR1, 2, and 6), lipopolysaccharide (LPS) (TLR4), or flagellin (TLR5), others recognize nucleic acid including 
double-stranded viral RNA (TLR3), single-stranded RNA (TLR7 and 8), or unmethylated bacterial DNA (TLR9). Both human and mouse $\gamma \delta$ T cells express functional TLRs. There are several studies showing TLR2 expression on $\gamma \delta$ T cells in mice $(26,27)$ and humans $(28)$, supporting a role in early responses to bacterial infections.

In mice, it has been shown that CCR6 ${ }^{+} \mathrm{IL}-17$-producing $\gamma \delta \mathrm{T}$ cells, but not other $\gamma \delta$ T cells, express TLR1 and TLR2, as well as dectin-1, and could directly interact with certain pathogens. Toll-like receptor (TLR) stimulation in synergy with IL-23 results in cell expansion, IL-17 production, and further recruitment of neutrophils in vivo (29). In addition, the expression of TLR1, TLR2, TLR-6, TLR-9, and even TLR- 4 by mice $\gamma \delta$ T cells has been confirmed (30). Furthermore, it has been shown that IL-23 stimulation of splenic $\gamma \delta$, but not $\alpha \beta$, T cells leads to enhanced TLR1, -2, and -4 mRNA expression. TLR2 agonist Pam3CSK4, but not IL-23, stimulates splenic $\gamma \delta \mathrm{T}$ cell expansion in vitro (30). However, TLR agonist Pam3CSK4 and other pathogen products alone do not stimulate dermal $\gamma \delta \mathrm{T}$ cell proliferation, which require IL-23 (31). Additionally, TLR agonists Pam3CSK4 (TLR2), Gardiquimod (TLR7), and CpG (TLR9), but not LPS (TLR4) or dectin-1 ligand curdlan, stimulate dermal $\gamma \delta$ T cells to produce IL-17, which is enhanced in the presence of IL-23 (31). It has also been reported that TLR4 is involved in the production of IL-17 and IFN- $\gamma$ by $\gamma \delta$ T cells during experimental autoimmune encephalomyelitis (EAE) induction (32).

In humans, the two major $\gamma \delta \mathrm{T}$ cell subsets, $\mathrm{V} \delta 1$ and $\mathrm{V} \delta 2$, express TLR1, TLR2, and TLR3 (33). Indeed, it has been demonstrated that human $\gamma \delta$ T cells isolated from blood express high levels of TLR2, and its engagement promotes the release of IFN $\gamma$ (28). Furthermore, the expression of TLR3 on human $\gamma \delta$ cells has been verified by flow cytometry and confocal microscopy (34). Human $\gamma \delta \mathrm{T}$ cells secrete IFN- $\gamma$ and upregulate CD69 after stimulation via TCR in the presence of poly (I:C), a TLR-3 agonist, without APC engagement (34).

In brief, $\gamma \delta \mathrm{T}$ cells rapidly respond after bacteria encounter secreting cytokines regulating the immune response, similarly to cells of the innate immunity (Figure 1A). Interestingly, human $\gamma \delta \mathrm{T}$ cells, after activation, express molecules typically found in APCs, involved in antigen presentation, such as MHC-II and CD86 $(33,35)$, and it has been shown that they are able to present soluble antigens activating conventional $\mathrm{T}$ cells. Furthermore, some reports have also shown that human $\gamma \delta$ T cells are able to phagocytose-opsonized beads and bacteria (36), presenting bacterial antigens on MHC class II (in vitro), highlighting the innate immune role of $\gamma \delta$ T cells. However, it remains to be elucidated whether the $\gamma \delta \mathrm{T}$ cell-mediated antigen presentation occurs in vivo during the course of bacterial infections and the relevance of such antigen presentation. Moreover, it is not clear if they could elicit a memory response.

\section{Invariant NKT}

Invariant NKT cells express an invariant $\mathrm{TCR} \alpha$ chain and recognize lipid and glycolipid antigens presented by CD1d, a non-polymorphic MHC class I molecule (37). They also express several receptors, such as NK1.1 (in some mouse strains), and members of the Ly49 family that are typical of the NK cell lineage. iNKT cells are most abundant in liver, thymus, spleen, and bone marrow, but are also found in lymph nodes, peripheral blood, adipose tissue, skin, and mucosal surfaces of intestine and lungs.

It has been described that iNKT cells participate in the response to microbial pathogens in mice $(38,39)$ (Figure 1B). Upon activation, they produce cytokines such as IL- 4 and IFN- $\gamma$. iNKTs can be activated by TCR stimulation with microbial antigens presented by CD1d (direct activation) or with endogenous antigens and/or cytokines (indirect activation) produced by APCs. The glycosphingolipid (GSL) $\alpha$-galactosyl ceramide $(\alpha$ GalCer) was the first antigen identified recognized by mouse [V $\alpha 14$ (40)] and human [V 224 (41)] iNKT cells. Recently, it has been described a novel GSL antigen for iNKT cells, DB06-1, which induces preferentially IFN- $\gamma$ in vivo in mice (42).

It has been reported that mouse iNKTs recognize cell wall GSL expressed by Sphingomonas spp., which are Gram-negative bacteria and have abundant GSLs, similar to $\alpha$ GalCer (43). Mice deficient of V $\alpha 14$ iNKT cells present reduced spirochete clearance and are more susceptible to chronic inflammation following Borrelia burgdorferi infection (44). Furthermore, iNKTs recognize glycolipids expressed by Helicobacter pilori (45) and diacylglycerol-containing glycolipids from Streptococcus pneumoniae and group B Streptococcus (46). After infection of mice with $S$. pneumoniae, V $\alpha 14$ iNKT cells produce IFN- $\gamma$, through TCR engagement (46). Recently, it has been shown that respiratory infection with Francisella tularensis, Gram-negative facultative intracellular bacteria that cause lethal pulmonary tularemia, activates iNKT cells which produce IFN- $\gamma$ and propagates a sepsis-like proinflammatory response (47).

On the other hand, it has been demonstrated in both humans and mice that the responses by iNKT to some bacteria, such as Salmonella typhimurium, is due to indirect recognition of endogenous lysosomal GSL expressed by activated DCs combined with TLR activation $(43,48)$.

\section{TLRs in iNKT Cells}

It has been found that mouse iNKT cells activated by TCR resulted in increased expression of TLRs (49). In this regard, TLR4 engagement is required for production of IL- 4 to further stimulate B-1 cells (50). The expression of TLR3 and 9 has been confirmed at protein level, and it has been shown that TLR signaling enhances iNKT activation. TLR stimulation of iNKT cells leads to IFN- $\gamma$, IL-4, and TNF- $\alpha$ production (51). On the other hand, although human iNKT cells express all TLRs, except from TLR8, they do not respond directly to TLR ligands (52).

\section{MAIT Cells}

Mucosal-associated invariant $\mathrm{T}$ cells express a semi-invariant TCR $\alpha$ chain that recognizes small molecules, pterin analogs, and riboflavin metabolites, presented by the non-polymorphic $\mathrm{MHC}$ class I-related molecule, MR1 (53). MR1 is highly conserved (90\% gene sequence identity between mouse and human), allowing for considerable species cross-reactivity of MAIT cells. Human MAIT cells develop effector capacity before exiting the thymus, in contrast to conventional $\mathrm{T}$ cells that remain naive until antigen stimulation in the periphery $(54,55)$. Human MAIT cells are 

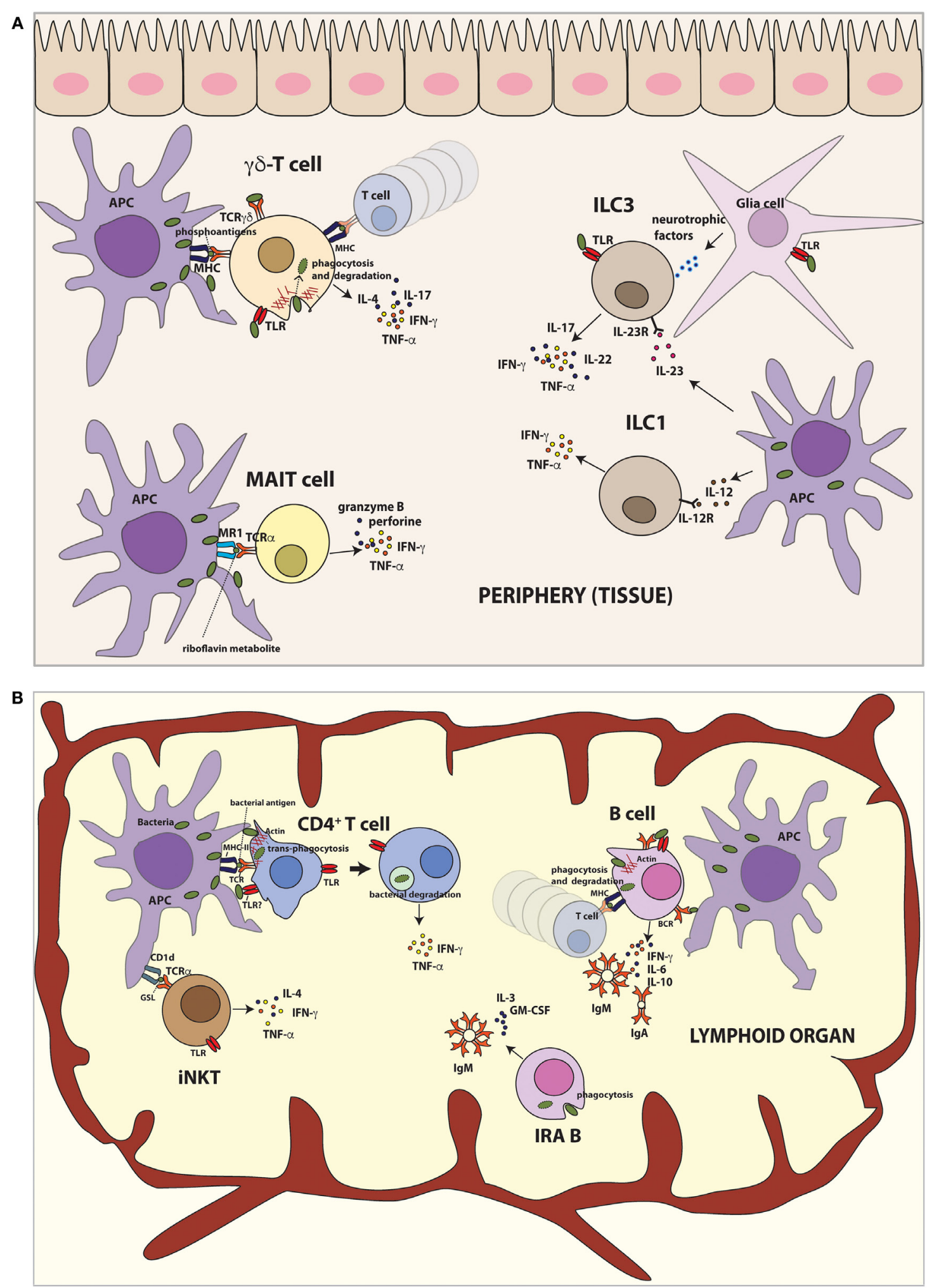

FIGURE 1 | Innate-like functions by different lymphoid cells after bacteria encounter. (A) Lymphoid populations in peripheral tissues. $\gamma \delta \top$ cells recognize non-peptide phosphoantigens derived from bacteria and induce production of TNF- $\alpha$, IFN- $\gamma$, IL-4, and IL-17. Moreover, human $\gamma \delta T$ cells are able to phagocytose bacteria and present bacterial antigens on MHC class II to activate T cells in vitro. TLR stimulation of $\gamma \delta$ T cells also results in IL-17 and IFN- $\gamma$ production. MAIT cells recognize microbial riboflavin metabolites presented by MR1 and produce TNF- $\alpha$ and IFN- $\gamma$. Furthermore, human MAIT cells destroy infected cells by secretion of 


\section{FIGURE 1 | Continued}

cytotoxic granzyme and perforin. ILC1 cells promote defense against intracellular bacteria by TNF- $\alpha$ and IFN- $\gamma$. ILC3 cells respond to extracellular bacteria, inducing mainly IL-17 and IL-22. TLR stimulation of ILC3 cells also results in secretion of proinflammatory cytokines such as TNF- $\alpha$ and IFN- $\gamma$ production. Mouse ILC3 cells can form a functional unit with glial cells in the epithelial gut sensing the environment in TLR-MyD88-dependent manner and control the immune response via IL-22 secretion. (B) Lymphoid populations in lymphoid organs. iNKT cells recognize bacterial glycosphingolipid (GSL) presented by CD1d and produce IFN- $\gamma$. Additionally, TLR engagement of iNKT cells leads to IFN- $\gamma$, IL-4, and TNF- $\alpha$ production. B cells capture soluble antigens or antigens exposed by APCs. On the other hand, they can phagocytose bacteria and present bacterial antigens to T lymphocytes. After bacteria encounter, B cells secrete large amount of IgM and/or IgA and proinflammatory cytokines. The newly recently described IRA B cells population protects against microbial sepsis, secreting IgM, IL-3, and GM-CSF. Human IRA B cells also phagocyte bacteria at least in vitro. Conventional CD4+ $\mathrm{T}$ cells can trans-phagocyte bacteria from infected dendritic cells (APCs) and secrete proinflammatory cytokines.

found principally in lungs, liver, and blood $(56,57)$, but they are less abundant in common laboratory mouse strains. Recently, it has been discovered that MAIT cells are more frequent in inbred CAST/EiJ mice than in C57BL/6 (58).

The role of MAIT cells in the control of bacterial infection was observed due to the absence of peripheral MAIT cells in germ-free mice and its expansion after microbial colonization (59). Both human and mouse MAIT cells can recognize bacterial (and fungi) infected cells in an MR1-dependet manner (56, 60). Human MAIT cells produce proinflammatory cytokines, e.g., IFN- $\gamma$ and TNF in response to infection with Mycobacterium smegmatis, Escherichia coli, Salmonella enterica, or Staphylococcus aureus (56). However, not all microorganisms tested can activate MAIT cells. Several bacteria, such as Enterococcus faecalis, group A Streptococcus, and L. monocytogenes, do not stimulate human and mouse MAIT cells, neither do viruses $(56,60)$. Indeed, only the microorganisms that can synthetize riboflavin metabolites which bind MR1 are able to activate MAIT cells (i.e., most bacteria and some fungi) $(53,61)$. In agreement, MAIT cells accumulation in lungs of mice infected with $S$. typhimurium depends on microbial riboflavin synthesis (62). However, despite the fact the viruses do not produce riboflavin, viral infections (e.g., HIV) can reduce the numbers of peripheral MAIT cells (by mechanisms that are not totally understood), therefore increasing the susceptibility to opportunistic infections of bacteria and fungi (63). Nevertheless, an open question remains to be elucidated is how MAIT cells are able to recognize specific pathogens. Recently, using MR1 tetramers, it has been identified populations of MR1-restricted cells which assist to have different antigen recognition in humans (64) and mice (65).

In addition to the secretion of inflammatory cytokines, human MAIT cells achieve antibacterial immunity destroying infected cells by secretion of cytotoxic granzyme and perforin $(66,67)$. The role of MAIT cells during an infection in vivo has been demonstrated using MR1-deficient mice. These mice infected with Klebsiella pneumoniae develop higher bacterial burden, hypothermia, and have increased mortality in the first 4 days of infection compared with infected WT mice (68). In other infection model, using Mycobacterium bacillus Calmette-Guérin (BCG), MR-1 deficient mice also show higher bacterial burden in the lung compared to the WT mice (69). In both models, protection by mouse MAIT cells occurs within the first days of the infection, suggesting that they act as innate lymphocytes (Figure 1A).

Finally, it remains unresolved whether MAIT cells expressed TLRs influencing its activation or function upon stimulation.

\section{B Lymphocytes}

It is well known that B-lymphocytes, components of the adaptive response and responsible for humoral immunity, are also APCs. They can capture soluble antigens or antigens exposed by macrophages, DCs, and follicular (FO) DCs (70). There are several subtypes of B cell lymphocytes that include B-1 (B-1a and $\mathrm{B}-1 \mathrm{~b})$ and conventional B-2 cells that comprise two populations designated as MZ and FO B cells.

\section{B-1 Cells}

B-1 cells are not considered part of the adaptive immune system, as they do not develop into memory cells. B-1 cells have been identified in both human and mouse, but due to the logistical difficulties in isolating B-1 cells of humans, the vast majority of the studies have been performed in mouse models (71). B-1 resides principally in the peritoneal and pleural cavities but is in a minor fraction in lymph nodes and spleen (72). B-1 cells in the peritoneal cavity express CD11b (Mac-1) and are subdivided based on the expression of CD5.

B-1 cells play a relevant role in innate immunity by their contribution in the first line of defense against bacterial infection. B-1 cells alter their normal migration patterns (73), accumulating rapidly in the omentum, lymph nodes, and spleen, following activation by stimuli, such as IL-10, IL-5 (74), TLR agonists, such as LPSs $(73,75)$, or even whole bacteria, such as $S$. pneumoniae (76) or Borrelia hermsii (77). The exit of these cells from peritoneal cavity in response of LPS or bacteria is controlled by myeloid differentiation primary response protein 88 (MyD88), a key adaptor for TLRs signaling, that downregulates the expression of integrins and CD9, thereby promoting cell migration (73). After migration, B-1 cells differentiate and secrete rapidly large amount of $\operatorname{IgM}$ and/or IgA $(73,75)$. They are able to produce antibodies in response to T-cell-independent type 2 antigens (mainly repetitive structures from encapsulated bacteria) along with MZ B cells (76).

Regarding the phagocytic capacity of B-1 cells after bacteria encounter, there are several reports showing that B-1 cells are able to phagocyte $S$. aureus, E. coli, and polystyrene fluorescent microspheres $(78,79)$. Upon phagocytosis, B-1 cells kill internalized bacteria via phagolysosomes and present bacterial antigens in MHC-II molecules $(78,79)$. Salmonella spp. has been shown to be degraded through both proteasomal and lysosomal processing, resulting in MHC-I antigen presentation (80). On the other hand, not all bacteria are killed; some Salmonella can survive within B cells, using therefore B cells as Trojan horses to disseminate through the infected host (81), similarly to what has 
been observed in myeloid cells (82). It has been also described that B-1 cells undergo differentiation to acquire a mononuclear phagocyte phenotype in vitro (B-1CDP), and they are able to phagocytose Coxiella burnetii and kill them more effectively than peritoneal macrophages and bone marrow-derived macrophages (BMMf) (83). Moreover, it has been demonstrated that B-1 cell differentiation into phagocytes occurs also in vivo (84). These results revealed that mammalian B-1 cells have phagocytic and microbicidal abilities to strengthen the innate nature of these cells (Figure 1B). In agreement with the innate behavior of $\mathrm{B} 1$ cells, a recent report shows that during aging, mouse B1 cells express high levels of the costimulatory molecule CD86 and become potent activators of $\mathrm{CD} 8^{+} \mathrm{T}$ cells, a role deserved for specialized populations of APCs (85).

\section{Conventional B-2 Cells}

The current consensus is that B-1 cells are phagocytic, whereas the phagocytic abilities of mouse conventional $\mathrm{B}$ cells and the mechanisms for bacterial uptake are less clear (79). BCR-blocking antibodies do not alter the internalization of bacteria, indicating that $\mathrm{BCR}$ is not involved in bacteria entry. In contrast to these data, it has been demonstrated that mouse liver B cells (both B-1 and B-2 cells) actively phagocytose and kill bacteria, such as $E$. coli, in a complement-dependent manner (86). Accordingly, it has been shown that splenic mouse $B$ cells can internalize opsonized Brucella abortus (87), but B. abortus can survive inside B cells. In addition, it has also been reported that $S$. typhimurium are able to infect and survive within both mouse splenic B-1 and B-2 cell subpopulations. Salmonella infection stimulates expression of PD-L1 on mouse B cells, suggesting that PD-1/PD-L1 pathway may be involved in turning off the cytotoxic effector response during persistent infection (80). Furthermore, it has been reported that human primary $\mathrm{B}$ cells are able to internalize S. typhimurium (88). This process is BCR mediated and leads to efficient antigen loading into MHC-II, inducing $\mathrm{CD} 4^{+} \mathrm{T}$ cell help to boost Salmonella-specific antibody production. Salmonellaspecific B cells that phagocytose Salmonella upon BCR ligation reactivate human memory $\mathrm{CD}^{+} \mathrm{T}$ cells via cross-presentation (89). Additionally, it has been demonstrated that both human peripheral blood and mouse splenic B-lymphocytes serve as a niche for intracellular Salmonella promoting systemic spreading of infection (81).

Conventional B-2 cells are divided into two populations designated as MZ and FO B cell. MZ B cells are a special population of mostly non-recirculating $B$ cells enriched primarily in the MZ of the spleen. They are one of the first cells that take contact with blood-borne pathogens, supporting the first line of host defense. Pathogens trapped in the MZ activate MZ B cells, which maturate to plasma cells secreting IgM or to APCs. It has been reported that MZ B cells capture, process, and present antigens to $\mathrm{T}$ cells more efficiently than FO B cells both in vitro (90) and in vivo (91). MZ B cells appear, therefore, as excellent APCs, which, together with lymphoid DCs, play essential roles in the initial steps of in vivo T-cell activation. Consequently, they participate in T-cell-dependent (TD) immune response through the capture and import of blood-borne antigens to FO areas of the spleen (91).
Mice depleted of MZ B cells and infected with B. burgdorferi show elevated pathogen burden and reduced levels of $B$. burgdorferi-specific IgG and IgM, correlated with diminished splenic $\mathrm{CD}^{+} \mathrm{T}$-cell responses (92). Similarly, these mice show an increased susceptibility to $S$. aureus (93). The clearance of the bacteria $L$. monocytogenes depends on the interactions between marginal zone macrophages (MZ M) and MZ B cells (94). MZ $M$ bind pathogens and capture antigens through various PRRs, including scavenger receptors and C-type lectin receptors (CLRs) (95), and then, they expose native antigens and establish direct cell-cell contact for the activation of MZ B cells (96) that are required for potent responses (94).

\section{TLRs in B Cells}

$\mathrm{B}$ cells can interact with bacteria via BCRs or TLRs. The expression and functionality of TLRs in B cells has been well characterized during last years. Both mouse and human B cells express a variety of TLRs (TLR1-10) $(97,98)$, but mouse TLR10 is not functional.

Bacterial proteins can regulate the expression of TLR in mouse B cells, such as Shigella dysenteriae porin, which increases the levels of TLR2, -4, and Myd88 on peritoneal B-1 cells (99). Stimulation of TLR in B cells can modify many effectors functions, and the effects depend on the development phase of $\mathrm{B}$ cell. TLR4 and 9 engagements at the immature and transitional B cell stage promote proliferation and survival (100). The proliferation of peritoneal B-1 cells in response to TLR stimulation is lower than splenic B-2 cells (101). On the other hand, TLR stimulation of mature $B$ cells promotes proinflammatory cytokines production $(102,103)$; MZ B cells produce IL-6 and IL-10, FO B cells secrete IFN- $\gamma$ and IL-6 (98), and peritoneal B-1 cells produce high levels of IL-10, limiting the clearance of B. hermsii infection (101). Moreover, many surface proteins are expressed in response to TLR signaling in B cells such as the receptors for $B$ cell-activating factor belonging to the TNF family (BAFF), an important B cell survival factor in the periphery, and APRIL $(97,104)$.

Toll-like receptor signaling in B cells can also result in differentiation into plasma cells or influence class switching and affinity maturation (105). TLR agonists stimulate the proliferation of mouse MZ B cells and their phenotypic maturation process, increasing MHC-II, CD40, and CD86 molecules. Depending on TLR agonist, they also secrete a distinct cytokine profile (106). TLR agonists also activate MZ B cells in vivo and promote the migration from the MZ, accelerating the Ag-specific IgM response (107). It is shown that $\mathrm{p} 110 \delta$ activity mediates TLR-induced proliferation and antibody responses by MZ B cells (108). Recently, it has been described that TLR4 stimulation can promote activation-induced cell death (AICD) in MZ B cells, increasing FasL and Fas expression, regulating T-cell-independent B cell responses (109).

In humans, TLR ligands can promote the differentiation of transitional B cells into MZ-like B cells, and patients with defective TLR signaling have reduced numbers of MZ B cells (110).

Therefore, TLR signaling in B cells induces functional responses including cytokine, immunoglobulin production, antigen presentation, proliferation, and modulation of several surface receptors. These responses depend on the B cell development stage. 


\section{Innate Response Activator Cells}

Innate response activator (IRA) $\mathrm{B}$ cells have recently been described as a $B$ cell population that protects against microbial sepsis in mice. They are accumulated in the spleen in a mouse model of sepsis and in response to E. coli infection, indicating that IRA B cell expansion is an overall characteristic of the body's reaction to bacteria (111). IRA B cells are different phenotypically and functionally from other B cell populations. They contain large amounts of intracellular IgM and spontaneously secrete IgM, but not IgA or IgG1. In addition, they are able to secrete granulocyte macrophage colony-stimulating factor (GM-CSF) and IL-3 (Figure 1B). IRA B cells derived from B-1 cell precursors are activated by TLR stimuli, and they protect against septic shock by controlling neutrophil-dependent bacterial clearance (111).

B-1a cells migrate to the lung in response to microbial airway infection, producing IgM. This process is depended on IRA B cells, which controls IgM production via autocrine GM-CSF signaling, conferring a first-line defense against bacteria in the lungs (112).

Recently, it has been described IRA B cells in humans. They reside in tonsils, within FO areas, which are the first route of defense from infection of the upper respiratory tract and are able to phagocyte bacteria, such as $S$. aureus, at least in vitro (113).

Therefore, IRA B cells seem to play important roles in bacterial clearance, but further work is required to clarify its function in vivo, and it remains to be studied whether IRA B cells directly interact with infecting bacteria and the nature of such interactions.

\section{Innate Lymphoid Cells}

Innate lymphoid cells are a recently identified member of the lymphoid lineage, which are enriched at epithelial barriers, such as skin, intestine, and lung, where contacts with microorganisms normally occur $(114,115)$. These innate lymphocytes mediate immune responses against infections and regulate homeostasis and inflammation $(116,117)$. They neither express TCRs or BCRs nor respond in an antigen-specific manner.

Innate lymphoid cells are divided into three subsets: group 1 ILCs (ILC1s and NK cells), group 2 ILCs (ILC2s), and group 3 ILCs (ILC3s and LTi cells). This nomenclature was unified to classify these emerging cell populations, which had been called by different terms including NK-22 cells, LTi-like cells, natural helper cells, nuocytes, and innate helper cells (118). ILCs are crucial in the protective immunity against bacteria (ILC1s and ILC3s) (119-121), intracellular parasites (ILC1s) (122), fungi (ILC3) (123), and parasitic worms (ILC2s) $(124,125)$.

\section{Group 1 ILCs}

Group 1 ILCs consisted of ILC1 and NK cells that produce IFN- $\gamma$ and TNF- $\alpha$ after stimuli (when stimulated by IL-12, IL-15, or IL-18) (126) and had the T-box transcription factor (T-bet) as a key transcription factor $(122,127,128)$. NKs were first described as innate lymphocytes with cytotoxic activity (129) that kills target cells. However, ILC1s are barely cytotoxic and seems to emerge from ILC3s (130) and are accumulated in inflamed mucosa tissue (131).

ILC1 populations have an important role in promoting defense against intracellular pathogens (Figure 1A). They secrete IFN- $\gamma$ and TNF- $\alpha$ in mice infected with oral pathogen Toxoplasma gondii, recruiting myeloid cells that cease infection (122).

However, recently, it has been demonstrated that ILC1s also are important in promoting immunity to extracellular bacteria such as Clostridium difficile (119).

The deficiency of IFN- $\gamma$ or T-bet-expressing ILC1s in Rag1 ${ }^{-/}$ mice increases susceptibility to C. difficile (119). Furthermore, it has been shown that Nfil3, an important transcription factor for the development of NKs and ILC1s, plays a role in the intestinal innate immune defense against acute bacterial infection with Citrobacter rodentium and C. difficile (132). Nfil3 deficiency results in more susceptibility to both intestinal pathogens but also corresponds to severely reduction of ILC3s and ILC2s, revealing a general requirement for this transcription factor in the development of all ILC lineages (132).

\section{Group 2 ILCs}

Group 2 ILCs, also referred as natural helper cells, noucytes, or innate helper 2 cells, are innate lymphocytes that produce IL-5 and IL-13 when stimulated with IL-25, IL-33, or thymic stromal lymphopoietin (TSLP) $(133,134)$. They were discovered after administration of IL-25 intranasally in Rag2 $2^{-/-}$mice, which lack conventional B and T cells $(135,136)$. ILC2s have been identified in fat tissue, spleen, nasal tissue, lung, intestine, and skin (137). ILC2 populations protect against helminth such as $N$. brasiliensis secreting IL-13 after infection $(124,133)$. IL-13 is necessary for the elimination of the parasite from the gastrointestinal tract, and transferring ILC2s into IL-13-deficient mice shows that IL-13 production by ILC2s is sufficient to resolve helminth infection (125). Moreover, it has been reported that ILC2s can promote IL-13-mediated immunity to other parasites in mice (138).

\section{Group 3 ILC: ILC3s}

Three groups characterized ILC3s in intestine as ILCs almost simultaneously $(120,139,140)$. ILC3 populations secrete IL-17A, IL-22, TNF- $\alpha$, and GM-CSF when activated (140-142). The transcription factor ROR $\gamma \mathrm{t}$ is an important regulator of this population (140). ILC3s are referred as NCR22 cells, NKp46 ILCs, ILC22s, and NKR-LTi cells in the literature. This family is described in mucosal tissues, particularly in the intestinal tract, where they mediate the balance between the immune system and the symbiotic microbiota (120). It has been recently shown that mouse ILC3 cells form a functional unit together with glial cells that sense the gut environment in a MyD88-dependent manner and control the immune response via IL-22 secretion (143) (Figure 1A). ILC3 populations rapidly respond to infection of mice either extracellular bacteria $(120,121,144)$ or fungi (123). ILC3s produce IL-22 after C. rodentium challenge in mice (140, 145), which is essential for host protection (146). IL-22 stimulates intestinal epithelial cells (IECs) to produce antimicrobial peptides and mucus, limiting the replication, dissemination, and tissue damage induced by pathogenic bacteria (116).

Similarly, ILC3s located in the oral mucosa produce IL-17 and IL-22 promoting immunity in mice against the fungal pathogen Candida albicans $(123,147)$. IL-17 acting alone or synergistically 
with IL-22 induces the recruitment of neutrophils to the site of infection. Moreover, it is shown that ILC3s also regulate neutrophils in neonatal mice, important for resistance to sepsis with Gram-negative opportunistic bacteria (148).

The production of IFN- $\gamma$ by T-bet-expressing ILC3 contributes to the protection of the epithelial barrier during against $S$. typhimurium infection in mice (149). On other hand, it has been described that the expression of IL-17 and IFN- $\gamma$ from ILC 3 s has been involved to drive inflammation in Helicobacter hepaticusinduced colitis (150), a mouse model of colitis. However, depletion of IL-22-producing ILCs localized in intestinal tissue results in peripheral dissemination of commensal bacteria, such as Alcaligenes species, promoting systemic inflammation (121). Consequently, these data indicate that ILCs regulate selective containment of lymphoid-resident bacteria to prevent systemic inflammation associated with chronic diseases.

ILC1s together with ILC3s mediate the recovery from $C$. difficile infection in mice (119). Previously, it has been suggested that ILC3s could play a role in the infection of these extracellular bacteria because the deficiency of the transcription factor Nfil3 resulted in a reduction of ILC3s with an increased of susceptibility to C. difficile infection (132). Nonetheless, it has been also demonstrated that ILC3s mediate protection against S. pneumoniae in respiratory tract (151).

\section{Group 3 ILCs: LTi Cells}

They are closely related to ILC3s, but their relationship is still controversial (114). LTi cells were first described in fetal and neonatal lymph nodes $(152,153)$, where they also showed that were crucial for lymphoid organogenesis. They are able to produce IL-17A and IL-22 mediating immunity to enteric pathogens $(154,155)$.

\section{TLRs in ILCs}

Mouse splenic ILC3s can produce IL-17 and IL-22 in vivo after contact with TLR2 ligands (154). Indeed, it has been shown that human ROR $\gamma \mathrm{t}^{+}$ILCs (LTi-like ILC) express functional TLR2, and its stimulation with agonists induces IL-5, IL-13, and IL-22 expression in a nuclear factor $\kappa \mathrm{B}(\mathrm{NF}-\kappa \mathrm{B})$-dependent manner (142). Recently, it has been reported that human ILCs isolated from duodenum biopsies express TLR2, 3, and 9, but only TLR3 agonists stimulate them to produce TNF- $\alpha$ and IFN- $\gamma$ (156).

The expression of TLRs in ILC2s has yet to be identified. There is a report showing that TLRs stimulation of purified ILC2s does not induce IL-9 (157), but further studies must be done to verify the expression and functionality of TLRs in these cells.

Natural killer cells and $\mathrm{NCR}^{+} \mathrm{ROR} \mathrm{t}^{+}$ILCSs (ILC3s) may interact directly with bacteria through natural cytotoxicity receptors (NCRs), such as NKp44 and NKp46, which can be activated by components derived form commensal bacteria $(158,159)$.

\section{Conventional T Cells}

In addition to the specialized lymphocyte populations with innate functions described above, we have recently described that conventional $\mathrm{CD}^{+} \mathrm{T}$ cells, the paradigm of the adaptive immunity, also play innate-like roles during bacterial infections, contrary to the current view of immunology (7). $\mathrm{CD} 4^{+} \mathrm{T}$ cells of both mouse and human origin are able to internalize different bacteria (pathogenic and non-pathogenic) such as L. monocytogenes, S. aureus, E. coli, and $S$. enterica from infected DCs, in a process called transinfection. Bacteria play a passive role in this process, driven by $\mathrm{T}$ cells (7); therefore, it would be more appropriate to term it transphagocytosis. Transphagocytic (ti) $\mathrm{CD} 4^{+} \mathrm{T}$ cells kill internalized bacteria in a manner reminiscent of innate immune cells and secrete proinflammatory Th- 1 cytokines (IFN- $\gamma$, TNF- $\alpha$, and IL-6) in a rapid innate-like response (Figure 1B). Furthermore, tiCD $4^{+} \mathrm{T}$ cells protect against bacterial infections in vivo, highly reducing the bacterial load found in liver and spleen 24 and $48 \mathrm{~h}$ after infections, contributing to the early innate immune response (7). This route of bacterial capture by $\mathrm{T}$ cells could be used for some pathogenic bacteria to spread. In this regard, it has been shown that $\mathrm{T}$ cells can serve as reservoir of bacteria in vivo (160-162). Moreover, Shigella flexneri manipulates the migration capacity of infected T cells in a type III secretion system-dependent manner (161-163). Transphagocytosis depends on T cell cytoskeleton, but the molecular mechanisms of how $\mathrm{T}$ cells can capture bacteria remain largely unknown. T cells are unable to directly capture bacteria (7); transphagocytosis requires $\mathrm{T}$ cell/DC intimate contact, and it is enhanced by antigen recognition by the TCR. On the other hand, $\mathrm{T}$ cells are unable to uptake latex beads from DCs, indicating that bacterial PAMPs are also involved in the transphagocytic process and suggest a role of T cell TLRs in this recently discovered process of bacterial uptake by $\mathrm{CD} 4^{+} \mathrm{T}$ cells.

\section{TLRs in Conventional T Cells}

The expression of almost all TLRs in CD4 ${ }^{+} \mathrm{T}$ cells, which would recognize bacterial PAMPs, has been identified at the mRNA level in $\mathrm{CD}^{+} \mathrm{T}$ cells $(164,165)$. However, it has been shown that activated mouse CD $4^{+}$T cells express TLR- 3 and TLR- 9 but not TLR-2 and TLR-4. Stimulation of TLR 3 and 9 enhances survival in a NF- $\kappa \mathrm{B}$ activation and is associated with Bcl-xL upregulation, without increased proliferation (166). On the contrary, it has been shown that TLR2 engagement induces Th1 activation in the absence of TCR stimulation, activating cell proliferation, cell survival, and IFN- $\gamma$ production. IL- 2 or IL-12 significantly enhances TLR-2-mediated IFN- $\gamma$ production through the augmented activation of MAPKs (167). Furthermore, it has been described that TLR2 stimulation by porin of $S$. dysenteriae directly promotes $\mathrm{CD}^{+} \mathrm{T}$ cell survival and proliferation in mouse cells (168). Human-activated $\mathrm{CD}^{+} \mathrm{T}$ cells express TLR2 and TLR4 mRNA, but only activated cells show quantifiable surface expression of either TLR by flow cytometry (169). TLR2 activation, but not TLR4, promotes proliferation and IFN- $\gamma$, IL- 2 , and TNF- $\alpha$ production in activated $\mathrm{CD}^{+} \mathrm{T}$ cells, indicating its costimulatory nature. In memory $\mathrm{CD}^{+} \mathrm{T}$ cells, TLR2 expression is constitutive, and its activation leads to proliferation and IFN- $\gamma$ production (169). On the other hand, TLR2 stimulation promotes Th17 differentiation both in vivo and in vitro, inducing proliferation and IL-17 production (30, 170). TLR9 stimulation in mouse $\mathrm{CD}^{+} \mathrm{T}$ cells induces NF- $\mathrm{KB}-$ dependent survival (166) and provides costimulation to $\mathrm{T}$ cells (171). TLR9 engagement, in combination with TCR activation, reduces irradiation-induced apoptosis in mouse $\mathrm{CD}^{+} \mathrm{T}$ cells and increases the rate of DNA repair (172). TLR9 stimulation in human effector CD4 ${ }^{+} \mathrm{T}$ cells promotes cell cycle entry (173). 
TLR3 stimulation also induces NF- $\kappa \mathrm{B}, \mathrm{MAPK}$, and the survival of CD4 ${ }^{+} \mathrm{T}$ cells (166). On the other hand, TLR5 engagement in combination with TCR activation results in increased proliferation and production of IL- 2 in human CD4 ${ }^{+} \mathrm{T}$ cells (174). TLR5 and TLR7/8 act also as costimulators, upregulating proliferation and IFN- $\gamma$, IL-8, and IL-10, but not IL-4, production by human $\mathrm{CD}^{+} \mathrm{T}$ cells (175). Moreover, engagement of TLR7 in human $\mathrm{CD}^{+} \mathrm{T}$ cells prevents cell cycle entry and proinflammatory cytokines production, by increasing intracellular calcium concentrations, which leads to dephosphorylation of NFATc2 and its translocation to the cell nucleus; this activates an anergic gene expression program (176).

\section{Lymphoid cells with Innate behaviour}

\section{Direct PAMPs recognition/ \\ TLR expression}
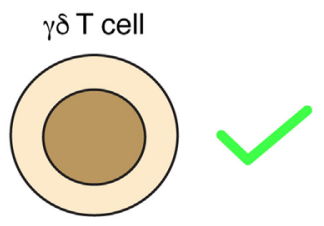

TLR $1,2,3$

$4,6,9$
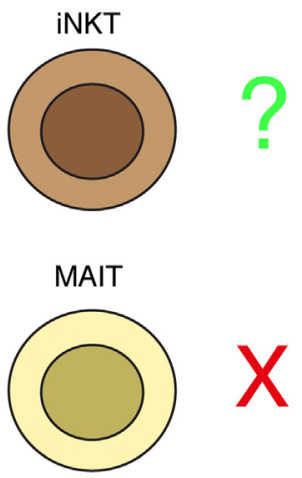

B cell

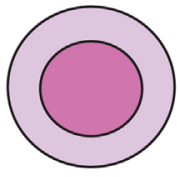

TLR 1,2,3,4,
$5,6,7,8,9,10$

Innate lymphoid cell
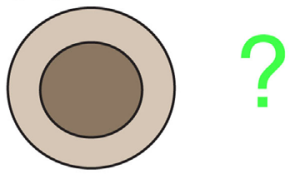

TLR 2,3,9

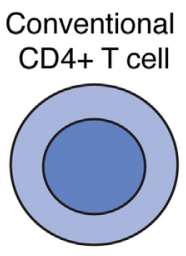

TLR 1,2,3 $4,5,7,9$

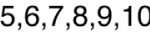

TLR 2,3,4, $5,7,9$
Rapid response/ cytokine secretion

IFN. $\gamma$, TNF $\alpha$ IL4,IL17,IL2

IFN. $\gamma$, TNF $\alpha$ IL4,IL2

IFN. $\gamma$, TNF $\alpha$ IL22,IL12

IFN. $\gamma$, IL6,IL10

IFN. $\gamma$, TNF $\alpha$ IL5,IL17,IL13 IL17A,IL22, GMCSF

IFN. $\gamma$, TNF $\alpha$ IL6

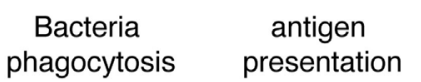

phagocytosis

resentation

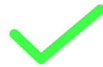

X

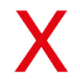

X

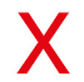

$x$
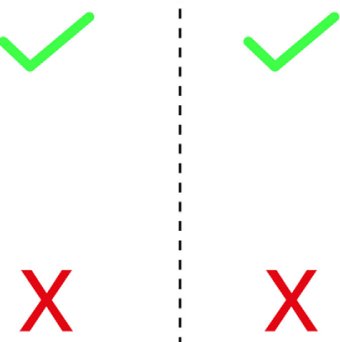

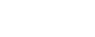
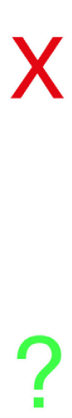

FIGURE 2 | Innate behaviors by lymphoid cells. Summary of different innate conducts by distinct populations of lymphoid cells. 
The role of $\mathrm{T}$ cell TLRs in bacterial capture and their roles in the recently described innate-like functions deserve future investigations.

\section{CONCLUSION AND FUTURE PERSPECTIVES}

Innate, rapid responses-sensing bacteria involve complex networks of cells working in a cooperative way [e.g., ILC3-glia cells collaboration (143)]. These responses include bacteria recognition by cellular PRRs, cytokine secretion, bacteria capture and killing by phagocytosis, and antigen presentation (Figure 2). Besides classical innate immune cells, specialized populations of lymphocytes, i.e., gamma delta $(\gamma / \delta)$ T, iNKT, MAIT, B-1, $\mathrm{MZ}$ B, and IRA B cells, behave in an innate-like manner, rapidly responding upon bacteria encounter. Surprisingly, it has been demonstrated that conventional lymphocytes (both $\mathrm{B}$ and $\mathrm{T}$ cells) can internalize bacteria in an innate-like manner. $\mathrm{CD}^{+}$ $\mathrm{T}$ cells can capture and kill bacteria by transphagocytosis from infected DCs. A similar way of bacteria capture from one infected cell to another has been also recently described for macrophages (177), and it is known from long as a mechanism from viral spread (i.e., HIV and hepatitis C virus) (178). The precise role of the $\mathrm{CD} 4^{+} \mathrm{T}$ cell-dependent bacterial clearance during infections in vivo remains to be determined, as the number of bacteria directly cleared by transphagocytosis seems to be low, suggesting other mechanisms for the reduction of bacterial load (i.e., cytokine release or antigen presentation). In agreement with this hypothesis, transphagocytic $\mathrm{T}$ cells secrete large amounts of proinflammatory cytokines, mounting a potent Th-1 response.

One of the hallmarks of the innate immunity is the antigenpresentation capacity of phagocytes; it has been proposed that gamma delta $\mathrm{T}$ cells are able to present antigen from degraded bacteria, and whether this occurs in vivo, and its role during infections, remains unknown. B1 cells (and B2) have the capacity

\section{REFERENCES}

1. Litman GW, Cannon JP, Dishaw LJ. Reconstructing immune phylogeny: new perspectives. Nat Rev Immunol (2005) 5:866-79. doi:10.1038/nri1712

2. Nikolich-Zugich J, Slifka MK, Messaoudi I. The many important facets of T-cell repertoire diversity. Nat Rev Immunol (2004) 4:123-32. doi:10.1038/ nri1292

3. Carrasco YR, Batista FD. B cells acquire particulate antigen in a macrophage-rich area at the boundary between the follicle and the subcapsular sinus of the lymph node. Immunity (2007) 27:160-71. doi:10.1016/j. immuni.2007.06.007

4. Lanier LL. Shades of grey - the blurring view of innate and adaptive immunity. Nat Rev Immunol (2013) 13:73-4. doi:10.1038/nri3389

5. Fan X, Rudensky AY. Hallmarks of tissue-resident lymphocytes. Cell (2016) 164:1198-211. doi:10.1016/j.cell.2016.02.048

6. Netea MG, Latz E, Mills KHG, O’Neill LAJ. Innate immune memory: a paradigm shift in understanding host defense. Nat Immunol (2015) 16:675-9. doi:10.1038/ni.3178

7. Cruz-Adalia A, Ramirez-Santiago G, Calabia-Linares C, Torres-Torresano M, Feo L, Galán-Díez M, et al. T cells kill bacteria captured by transinfection from dendritic cells and confer protection in mice. Cell Host Microbe (2014) 15:611-22. doi:10.1016/j.chom.2014.04.006 of present antigens and this ability, in addition to play a major role during infections, has been used for years to study the molecular mechanisms of T cell activation occurring during the immunological synapse in vitro. Whether recently discovered transphagocytic $\mathrm{T}$ cells (7) are able to present antigens from engulfed and killed bacteria remains unsolved and deserve further investigations. Indeed, it has been demonstrated that human $\mathrm{T}$ cells can process and present soluble antigens to stimulate other T lymphocytes $(179,180)$.

A major issue of the lymphocyte's innate-like responses is bacteria recognition. It is not fully clear which cellular receptors are involved in this process. TLRs are membrane-bound PRR involved in the recognition of extracellular PAMPs, initially characterized in innate immune cells. The expression of several TLRs has been found in the different subsets of lymphocytes, even in conventional $\mathrm{T}$ and $\mathrm{B}$ cells. Therefore, TLRs seem to be the best candidates for innate-like recognition of bacteria by lymphocytes. Bacterial recognition by lymphocytes during innatelike responses and the role that TLRs would play deserve future research. Due to the similarities in TLRs activation between bacterial PAMPs and danger signals found in malignant cells, the study of lymphocyte activation by bacteria could improve the immunotherapies against cancer.

\section{AUTHOR CONTRIBUTIONS}

Both EV and AC-A contribute equally to this work. Both are also co-corresponding authors.

\section{ACKNOWLEDGMENTS}

This work was supported by the grants from the Spanish Ministry of Science and Technology (MICINN; BFU2011-29450) to EV and Ministry of Economy and Competitiveness (MINECO; SAF2014-58895-JIN to AC-A and SAF2014-56716-REDT and BFU2014-59585-R to EV).

8. Saito H, Kranz DM, Takagaki Y, Hayday AC, Eisen HN, Tonegawa S. Complete primary structure of a heterodimeric T-cell receptor deduced from cDNA sequences. Nature (1984) 309:757-62. doi:10.1038/309757a0

9. Vantourout P, Hayday A. Six-of-the-best: unique contributions of $\gamma \delta$ T cells to immunology. Nat Rev Immunol (2013) 13:88-100. doi:10.1038/nri3384

10. Fay NS, Larson EC, Jameson JM. Chronic inflammation and $\gamma \delta \mathrm{T}$ cells. Front Immunol (2016) 7:210. doi:10.3389/fimmu.2016.00210

11. Hara T, Mizuno Y, Takaki K, Takada H, Akeda H, Aoki T, et al. Predominant activation and expansion of $\mathrm{V}$ gamma 9-bearing gamma delta $\mathrm{T}$ cells in vivo as well as in vitro in Salmonella infection. J Clin Invest (1992) 90:204-10. doi:10.1172/JCI115837

12. Morita CT, Beckman EM, Bukowski JF, Tanaka Y, Band H, Bloom $\mathrm{BR}$, et al. Direct presentation of nonpeptide prenyl pyrophosphate antigens to human gamma delta $\mathrm{T}$ cells. Immunity (1995) 3:495-507. doi:10.1016/1074-7613(95)90178-7

13. Chen ZW. Multifunctional immune responses of HMBPP-specific V $\gamma 2 \mathrm{~V} \delta 2$ T cells in M. tuberculosis and other infections. Cell Mol Immunol (2013) 10:58-64. doi:10.1038/cmi.2012.46

14. Bukowski JF, Morita CT, Brenner MB. Human gamma delta $\mathrm{T}$ cells recognize alkylamines derived from microbes, edible plants, and tea: implications for innate immunity. Immunity (1999) 11:57-65. doi:10.1016/ S1074-7613(00)80081-3 
15. Morita C, Lee H, Leslie D, Tanaka Y, Bukowski J, Märker-Hermann E. Recognition of nonpeptide prenyl pyrophosphate antigens by human gammadelta T cells. Microbes Infect (1999) 1:175-86. doi:10.1016/S12864579(99)80032-X

16. Constant P, Davodeau F, Peyrat MA, Poquet Y, Puzo G, Bonneville M, et al. Stimulation of human gamma delta $\mathrm{T}$ cells by nonpeptidic mycobacterial ligands. Science (1994) 264:267-70. doi:10.1126/science.8146660

17. Guo Y, Ziegler HK, Safley SA, Niesel DW, Vaidya S, Klimpel GR. Human T-cell recognition of Listeria monocytogenes: recognition of listeriolysin $\mathrm{O}$ by TcR alpha beta+ and TcR gamma delta+ T cells. Infect Immun (1995) 63:2288-94.

18. Lang F, Peyrat MA, Constant P, Davodeau F, David-Ameline J, Poquet Y, et al. Early activation of human $\mathrm{V}$ gamma $9 \mathrm{~V}$ delta $2 \mathrm{~T}$ cell broad cytotoxicity and TNF production by nonpeptidic mycobacterial ligands. J Immunol (1995) 154:5986-94.

19. Romi B, Soldaini E, Pancotto L, Castellino F, Del Giudice G, Schiavetti F. Helicobacter pylori induces activation of human peripheral $\gamma \delta+$ T lymphocytes. PLoS One (2011) 6:e19324. doi:10.1371/journal.pone.0019324

20. Hiromatsu K, Yoshikai Y, Matsuzaki G, Ohga S, Muramori K, Matsumoto K, et al. A protective role of gamma/delta $\mathrm{T}$ cells in primary infection with Listeria monocytogenes in mice. J Exp Med (1992) 175:49-56. doi:10.1084/ jem.175.1.49

21. Emoto M, Danbara H, Yoshikai Y. Induction of gamma/delta $\mathrm{T}$ cells in murine salmonellosis by an avirulent but not by a virulent strain of Salmonella choleraesuis. J Exp Med (1992) 176:363-72. doi:10.1084/jem.176. 2.363

22. Janis EM, Kaufmann SH, Schwartz RH, Pardoll DM. Activation of gamma delta $\mathrm{T}$ cells in the primary immune response to Mycobacterium tuberculosis. Science (1989) 244:713-6. doi:10.1126/science.2524098

23. Ferrick DA, Schrenzel MD, Mulvania T, Hsieh B, Ferlin WG, Lepper H. Differential production of interferon-gamma and interleukin- 4 in response to Th1- and Th2-stimulating pathogens by gamma delta T cells in vivo. Nature (1995) 373:255-7. doi:10.1038/373255a0

24. Hirota K, Duarte JH, Veldhoen M, Hornsby E, Li Y, Cua DJ, et al. Fate mapping of IL-17-producing T cells in inflammatory responses. Nat Immunol (2011) 12:255-63. doi:10.1038/ni.1993

25. Sheridan BS, Romagnoli PA, Pham Q-M, Fu H-H, Alonzo F, Schubert W-D, et al. $\gamma \delta \mathrm{T}$ cells exhibit multifunctional and protective memory in intestinal tissues. Immunity (2013) 39:184-95. doi:10.1016/j.immuni.2013.06.015

26. Mokuno Y, Matsuguchi T, Takano M, Nishimura H, Washizu J, Ogawa T, et al. Expression of toll-like receptor 2 on gamma delta $\mathrm{T}$ cells bearing invariant $\mathrm{V}$ gamma 6/V delta 1 induced by Escherichia coli infection in mice. J Immunol (2000) 165:931-40. doi:10.4049/jimmunol.165.2.931

27. Schwacha MG, Daniel T. Up-regulation of cell surface toll-like receptors on circulating gammadelta T-cells following burn injury. Cytokine (2008) 44:328-34. doi:10.1016/j.cyto.2008.09.001

28. Deetz CO, Hebbeler AM, Propp NA, Cairo C, Tikhonov I, Pauza CD. Gamma interferon secretion by human Vgamma2Vdelta2 $\mathrm{T}$ cells after stimulation with antibody against the T-cell receptor plus the toll-like receptor 2 agonist Pam3Cys. Infect Immun (2006) 74:4505-11. doi:10.1128/IAI. 00088-06

29. Martin B, Hirota K, Cua DJ, Stockinger B, Veldhoen M. Interleukin-17producing gammadelta $\mathrm{T}$ cells selectively expand in response to pathogen products and environmental signals. Immunity (2009) 31:321-30. doi:10.1016/j.immuni.2009.06.020

30. Reynolds JM, Pappu BP, Peng J, Martinez GJ, Zhang Y, Chung Y, et al. Tolllike receptor 2 signaling in $\mathrm{CD} 4(+) \mathrm{T}$ lymphocytes promotes $\mathrm{T}$ helper 17 responses and regulates the pathogenesis of autoimmune disease. Immunity (2010) 32:692-702. doi:10.1016/j.immuni.2010.04.010

31. Cai Y, Shen X, Ding C, Qi C, Li K, Li X, et al. Pivotal role of dermal IL-17producing $\gamma \delta \mathrm{T}$ cells in skin inflammation. Immunity (2011) 35:596-610. doi:10.1016/j.immuni.2011.08.001

32. Reynolds JM, Martinez GJ, Chung Y, Dong C. Toll-like receptor 4 signaling in T cells promotes autoimmune inflammation. Proc Natl Acad Sci U S A (2012) 109:13064-9. doi:10.1073/pnas.1120585109

33. Kress E, Hedges JF, Jutila MA. Distinct gene expression in human V $\delta 1$ and V $22 \gamma \delta$ T cells following non-TCR agonist stimulation. Mol Immunol (2006) 43:2002-11. doi:10.1016/j.molimm.2005.11.011
34. Wesch D, Beetz S, Oberg H-H, Marget M, Krengel K, Kabelitz D. Direct costimulatory effect of TLR3 ligand poly(I:C) on human gamma delta T lymphocytes. J Immunol (2006) 176:1348-54. doi:10.4049/jimmunol. 176.3.1348

35. Brandes M, Willimann K, Moser B. Professional antigen-presentation function by human gammadelta T cells. Science (2005) 309:264-8. doi:10.1126/ science. 1110267

36. Wu Y, Wu W, Wong WM, Ward E, Thrasher AJ, Goldblatt D, et al. Human T cells: a lymphoid lineage cell capable of professional phagocytosis. J Immunol (2009) 183:5622-9. doi:10.4049/jimmunol.0901772

37. Borg NA, Wun KS, Kjer-Nielsen L, Wilce MCJ, Pellicci DG, Koh R, et al. CD1d-lipid-antigen recognition by the semi-invariant NKT T-cell receptor. Nature (2007) 448:44-9. doi:10.1038/nature05907

38. Ranson T, Bregenholt S, Lehuen A, Gaillot O, Leite-de-Moraes MC, Herbelin A, et al. Invariant V alpha 14+ NKT cells participate in the early response to enteric Listeria monocytogenes infection. J Immunol (2005) 175:1137-44. doi:10.4049/jimmunol.175.2.1137

39. Sada-Ovalle I, Chiba A, Gonzales A, Brenner MB, Behar SM. Innate invariant NKT cells recognize Mycobacterium tuberculosis-infected macrophages, produce interferon-gamma, and kill intracellular bacteria. PLoS Pathog (2008) 4:e1000239. doi:10.1371/journal.ppat.1000239

40. Kawano T, Cui J, Koezuka Y, Toura I, Kaneko Y, Motoki K, et al. CD1drestricted and TCR-mediated activation of valpha14 NKT cells by glycosylceramides. Science (1997) 278:1626-9. doi:10.1126/science.278. 5343.1626

41. Nieda M, Nicol A, Koezuka Y, Kikuchi A, Takahashi T, Nakamura H, et al. Activation of human Valpha24NKT cells by alpha-glycosylceramide in a CD1d-restricted and Valpha24TCR-mediated manner. Hum Immunol (1999) 60:10-9. doi:10.1016/S0198-8859(98)00100-1

42. Birkholz AM, Girardi E, Wingender G, Khurana A, Wang J, Zhao M, et al. A novel glycolipid antigen for NKT cells that preferentially induces IFN- $\gamma$ production. J Immunol (2015) 195:924-33. doi:10.4049/jimmunol.1500070

43. Mattner J, Debord KL, Ismail N, Goff RD, Cantu C, Zhou D, et al. Exogenous and endogenous glycolipid antigens activate NKT cells during microbial infections. Nature (2005) 434:525-9. doi:10.1038/nature03408

44. Tupin E, Benhnia MR-E-I, Kinjo Y, Patsey R, Lena CJ, Haller MC, et al. NKT cells prevent chronic joint inflammation after infection with Borrelia burgdorferi. Proc Natl Acad Sci U S A (2008) 105:19863-8. doi:10.1073/ pnas.0810519105

45. Chang Y-J, Kim HY, Albacker LA, Lee HH, Baumgarth N, Akira S, et al. Influenza infection in suckling mice expands an NKT cell subset that protects against airway hyperreactivity. J Clin Invest (2011) 121:57-69. doi:10.1172/ JCI44845

46. Kinjo Y, Illarionov P, Vela JL, Pei B, Girardi E, Li X, et al. Invariant natural killer T cells recognize glycolipids from pathogenic Gram-positive bacteria. Nat Immunol (2011) 12:966-74. doi:10.1038/ni.2096

47. Hill TM, Gilchuk P, Cicek BB, Osina MA, Boyd KL, Durrant DM, et al. Border patrol gone awry: lung NKT cell activation by Francisella tularensis exacerbates tularemia-like disease. PLoS Pathog (2015) 11:e1004975. doi:10.1371/ journal.ppat.1004975

48. Brigl M, Bry L, Kent SC, Gumperz JE, Brenner MB. Mechanism of CD1drestricted natural killer $\mathrm{T}$ cell activation during microbial infection. Nat Immunol (2003) 4:1230-7. doi:10.1038/ni1002

49. Kulkarni RR, Villanueva AI, Elawadli I, Jayanth P, Read LR, Haeryfar SMM, et al. Costimulatory activation of murine invariant natural killer $\mathrm{T}$ cells by toll-like receptor agonists. Cell Immunol (2012) 277:33-43. doi:10.1016/j. cellimm.2012.06.002

50. Askenase PW, Itakura A, Leite-de-Moraes MC, Lisbonne M, Roongapinun S, Goldstein DR, et al. TLR-dependent IL-4 production by invariant Valpha14+Jalpha18+ NKT cells to initiate contact sensitivity in vivo. J Immunol (2005) 175:6390-401. doi:10.4049/jimmunol.175.10.6390

51. Villanueva AI, Haeryfar SMM, Mallard BA, Kulkarni RR, Sharif S. Functions of invariant NK T cells are modulated by TLR ligands and IFN- $\alpha$. Innate Immun (2015) 21:275-88. doi:10.1177/1753425914527327

52. Moreno M, Mol BM, Mensdorff-Pouilly von S, Verheijen RHM, de Jong EC, Blomberg von BME, et al. Differential indirect activation of human invariant natural killer T cells by toll-like receptor agonists. Immunotherapy (2009) 1:557-70. doi:10.2217/imt.09.30 
53. Kjer-Nielsen L, Patel O, Corbett AJ, Le Nours J, Meehan B, Liu L, et al. MR1 presents microbial vitamin B metabolites to MAIT cells. Nature (2012) 491:717-23. doi:10.1038/nature11605

54. Gold MC, Ehlinger HD, Cook MS, Smyk-Pearson SK, Wille PT, Ungerleider RM, et al. Human innate Mycobacterium tuberculosis-reactive alphabeta TCR+ thymocytes. PLoS Pathog (2008) 4:e39. doi:10.1371/ journal.ppat.0040039

55. Gold MC, Eid T, Smyk-Pearson S, Eberling Y, Swarbrick GM, Langley SM, et al. Human thymic MR1-restricted MAIT cells are innate pathogen-reactive effectors that adapt following thymic egress. Mucosal Immunol (2013) 6:35-44. doi:10.1038/mi.2012.45

56. Gold MC, Cerri S, Smyk-Pearson S, Cansler ME, Vogt TM, Delepine J, et al. Human mucosal associated invariant $\mathrm{T}$ cells detect bacterially infected cells. PLoS Biol (2010) 8:e1000407. doi:10.1371/journal.pbio.1000407

57. Jeffery HC, van Wilgenburg B, Kurioka A, Parekh K, Stirling K, Roberts S, et al. Biliary epithelium and liver B cells exposed to bacteria activate intrahepatic MAIT cells through MR1. J Hepatol (2016) 64:1118-27. doi:10.1016/j. jhep.2015.12.017

58. Cui Y, Franciszkiewicz K, Mburu YK, Mondot S, Le Bourhis L, Premel V, et al. Mucosal-associated invariant $\mathrm{T}$ cell-rich congenic mouse strain allows functional evaluation. J Clin Invest (2015) 125:4171-85. doi:10.1172/JCI82424

59. Treiner E, Duban L, Bahram S, Radosavljevic M, Wanner V, Tilloy F, et al. Selection of evolutionarily conserved mucosal-associated invariant $\mathrm{T}$ cells by MR1. Nature (2003) 422:164-9. doi:10.1038/nature01433

60. Le Bourhis L, Martin E, Péguillet I, Guihot A, Froux N, Coré M, et al. Antimicrobial activity of mucosal-associated invariant T cells. Nat Immunol (2010) 11:701-8. doi:10.1038/ni.1890

61. Soudais C, Samassa F, Sarkis M, Le Bourhis L, Bessoles S, Blanot D, et al. In vitro and in vivo analysis of the Gram-negative bacteria-derived riboflavin precursor derivatives activating mouse MAIT cells. JImmunol (2015) 194:4641-9. doi:10.4049/jimmunol.1403224

62. Chen Z, Wang H, D'Souza C, Sun S, Kostenko L, Eckle SBG, et al. Mucosalassociated invariant $\mathrm{T}$-cell activation and accumulation after in vivo infection depends on microbial riboflavin synthesis and co-stimulatory signals. Mucosal Immunol (2016). doi:10.1038/mi.2016.39

63. Saeidi A, Ellegård R, Yong YK, Tan HY, Velu V, Ussher JE, et al. Functional role of mucosal-associated invariant T cells in HIV infection. J Leukoc Biol (2016) 100:305-14. doi:10.1189/jlb.4RU0216-084R

64. Gherardin NA, Keller AN, Woolley RE, Le Nours J, Ritchie DS, Neeson PJ, et al. Diversity of T cells restricted by the MHC class I-related molecule MR1 facilitates differential antigen recognition. Immunity (2016) 44:32-45. doi:10.1016/j.immuni.2015.12.005

65. Sakala IG, Kjer-Nielsen L, Eickhoff CS, Wang X, Blazevic A, Liu L, et al. Functional heterogeneity and antimycobacterial effects of mouse mucosal-associated invariant T cells specific for riboflavin metabolites. J Immunol (2015) 195:587-601. doi:10.4049/jimmunol.1402545

66. Le Bourhis L, Dusseaux M, Bohineust A, Bessoles S, Martin E, Premel V, et al. MAIT cells detect and efficiently lyse bacterially-infected epithelial cells. PLoS Pathog (2013) 9:e1003681. doi:10.1371/journal.ppat.1003681

67. Kurioka A, Ussher JE, Cosgrove C, Clough C, Fergusson JR, Smith K, et al. MAIT cells are licensed through granzyme exchange to kill bacterially sensitized targets. Mucosal Immunol (2015) 8:429-40. doi:10.1038/mi.2014.81

68. Georgel P, Radosavljevic M, Macquin C, Bahram S. The non-conventional MHC class I MR1 molecule controls infection by Klebsiella pneumoniae in mice. Mol Immunol (2011) 48:769-75. doi:10.1016/j.molimm.2010.12.002

69. Chua W-J, Truscott SM, Eickhoff CS, Blazevic A, Hoft DF, Hansen TH. Polyclonal mucosa-associated invariant $\mathrm{T}$ cells have unique innate functions in bacterial infection. Infect Immun (2012) 80:3256-67. doi:10.1128/ IAI.00279-12

70. Batista FD, Iber D, Neuberger MS. B cells acquire antigen from target cells after synapse formation. Nature (2001) 411:489-94. doi:10.1038/35078099

71. Tangye SG. To B1 or not to B1: that really is still the question! Blood (2013) 121:5109-10. doi:10.1182/blood-2013-05-500074

72. Hayakawa K, Hardy RR, Herzenberg LA, Herzenberg LA. Progenitors for Ly-1 B cells are distinct from progenitors for other B cells. J Exp Med (1985) 161:1554-68. doi:10.1084/jem.161.6.1554

73. Ha S-A, Tsuji M, Suzuki K, Meek B, Yasuda N, Kaisho T, et al. Regulation of B1 cell migration by signals through toll-like receptors. J Exp Med (2006) 203:2541-50. doi:10.1084/jem.20061041
74. Nisitani S, Tsubata T, Murakami M, Honjo T. Administration of interleukin-5 or - 10 activates peritoneal B-1 cells and induces autoimmune hemolytic anemia in anti-erythrocyte autoantibody-transgenic mice. Eur J Immunol (1995) 25:3047-52. doi:10.1002/eji.1830251110

75. Murakami M, Tsubata T, Shinkura R, Nisitani S, Okamoto M, Yoshioka H, et al. Oral administration of lipopolysaccharides activates B-1 cells in the peritoneal cavity and lamina propria of the gut and induces autoimmune symptoms in an autoantibody transgenic mouse. J Exp Med (1994) 180:11121. doi:10.1084/jem.180.1.111

76. Martin F, Oliver AM, Kearney JF. Marginal zone and B1 B cells unite in the early response against $\mathrm{T}$-independent blood-borne particulate antigens. Immunity (2001) 14:617-29. doi:10.1016/S1074-7613(01)00129-7

77. Alugupalli KR, Leong JM, Woodland RT, Muramatsu M, Honjo T, Gerstein RM. B1b lymphocytes confer T cell-independent long-lasting immunity. Immunity (2004) 21:379-90. doi:10.1016/j.immuni.2004.06.019

78. Gao J, Ma X, Gu W, Fu M, An J, Xing Y, et al. Novel functions of murine B1 cells: active phagocytic and microbicidal abilities. Eur J Immunol (2012) 42:982-92. doi:10.1002/eji.201141519

79. Parra D, Rieger AM, Li J, Zhang Y-A, Randall LM, Hunter CA, et al. Pivotal advance: peritoneal cavity B-1 B cells have phagocytic and microbicidal capacities and present phagocytosed antigen to CD4+ T cells. J Leukoc Biol (2012) 91:525-36. doi:10.1189/jlb.0711372

80. Lopez-Medina M, Pérez-López A, Alpuche-Aranda C, Ortiz-Navarrete V. Salmonella induces PD-L1 expression in B cells. Immunol Lett (2015) 167:131-40. doi:10.1016/j.imlet.2015.08.004

81. Souwer Y, Griekspoor A, de Wit J, Martinoli C, Zagato E, Janssen H, et al. Selective infection of antigen-specific B lymphocytes by Salmonella mediates bacterial survival and systemic spreading of infection. PLoS One (2012) 7:e50667. doi:10.1371/journal.pone.0050667

82. Cohen TS, Hilliard JJ, Jones-Nelson O, Keller AE, ODay T, Tkaczyk C, et al. Staphylococcus aureus toxin potentiates opportunistic bacterial lung infections. Sci Transl Med (2016) 8:ra31-329. doi:10.1126/scitranslmed. aad9922

83. Popi AF, Zamboni DS, Mortara RA, Mariano M. Microbicidal property of B1 cell derived mononuclear phagocyte. Immunobiology (2009) 214:664-73. doi:10.1016/j.imbio.2008.12.007

84. Popi AF, Osugui L, Perez KR, Longo-Maugéri IM, Mariano M. Could a B-1 cell derived phagocyte "be one" of the peritoneal macrophages during LPS-driven inflammation? PLoS One (2012) 7:e34570. doi:10.1371/journal. pone. 0034570

85. Lee-Chang C, Bodogai M, Moritoh K, Chen X, Wersto R, Sen R, et al. Aging converts innate B1a cells into potent CD8+ T cell inducers. J Immunol (2016) 196:3385-97. doi:10.4049/jimmunol.1502034

86. Nakashima M, Kinoshita M, Nakashima H, Habu Y, Miyazaki H, Shono S, et al. Pivotal advance: characterization of mouse liver phagocytic B cells in innate immunity. J Leukoc Biol (2012) 91:537-46. doi:10.1189/jlb.0411214

87. Goenka R, Guirnalda PD, Black SJ, Baldwin CLB. Lymphocytes provide an infection niche for intracellular bacterium Brucella abortus. J Iinfect Dis (2012) 206:91-8. doi:10.1093/infdis/jis310

88. Souwer Y, Griekspoor A, Jorritsma T, de Wit J, Janssen H, Neefjes J, et al. B cell receptor-mediated internalization of Salmonella: a novel pathway for autonomous B cell activation and antibody production. J Immunol (2009) 182:7473-81. doi:10.4049/jimmunol.0802831

89. de Wit J, Souwer Y, Jorritsma T, Klaasse Bos H, Brinke ten A, Neefjes J, et al. Antigen-specific $\mathrm{B}$ cells reactivate an effective cytotoxic $\mathrm{T}$ cell response against phagocytosed Salmonella through cross-presentation. PLoS One (2010) 5:e13016. doi:10.1371/journal.pone.0013016.g005

90. Oliver AM, Martin F, Kearney JF. IgMhighCD21high lymphocytes enriched in the splenic marginal zone generate effector cells more rapidly than the bulk of follicular B cells. J Immunol (1999) 162:7198-207.

91. Attanavanich K, Kearney JF. Marginal zone, but not follicular B cells, are potent activators of naive CD4 T cells. J Immunol (2004) 172:803-11. doi:10.4049/jimmunol.172.2.803

92. Belperron AA, Dailey CM, Booth CJ, Bockenstedt LK. Marginal zone B-cell depletion impairs murine host defense against Borrelia burgdorferi infection. Infect Immun (2007) 75:3354-60. doi:10.1128/IAI.00422-07

93. Tanigaki K, Han H, Yamamoto N, Tashiro K, Ikegawa M, Kuroda K, et al. Notch-RBP-J signaling is involved in cell fate determination of marginal zone B cells. Nat Immunol (2002) 3:443-50. doi:10.1038/ni793 
94. Aichele P, Zinke J, Grode L, Schwendener RA, Kaufmann SHE, Seiler P. Macrophages of the splenic marginal zone are essential for trapping of bloodborne particulate antigen but dispensable for induction of specific $\mathrm{T}$ cell responses. J Immunol (2003) 171:1148-55. doi:10.4049/jimmunol.171.3.1148

95. Kang Y-S, Do Y, Lee H-K, Park SH, Cheong C, Lynch RM, et al. A dominant complement fixation pathway for pneumococcal polysaccharides initiated by SIGN-R1 interacting with C1q. Cell (2006) 125:47-58. doi:10.1016/j. cell.2006.01.046

96. Bergtold A, Desai DD, Gavhane A, Clynes R. Cell surface recycling of internalized antigen permits dendritic cell priming of B cells. Immunity (2005) 23:503-14. doi:10.1016/j.immuni.2005.09.013

97. Treml LS, Carlesso G, Hoek KL, Stadanlick JE, Kambayashi T, Bram RJ, et al. TLR stimulation modifies BLyS receptor expression in follicular and marginal zone B cells. JImmunol (2007) 178:7531-9. doi:10.4049/ jimmunol.178.12.7531

98. Barr TA, Brown S, Ryan G, Zhao J, Gray D. TLR-mediated stimulation of APC: distinct cytokine responses of B cells and dendritic cells. Eur J Immunol (2007) 37:3040-53. doi:10.1002/eji.200636483

99. Ray A, Karmakar P, Biswas T. Up-regulation of CD80-CD86 and IgA on mouse peritoneal B-1 cells by porin of Shigella dysenteriae is toll-like receptors 2 and 6 dependent. Mol Immunol (2004) 41:1167-75. doi:10.1016/j. molimm.2004.06.007

100. Wechsler-Reya RJ, Monroe JG. Lipopolysaccharide prevents apoptosis and induces responsiveness to antigen receptor cross-linking in immature $B$ cells. Immunology (1996) 89:356-62. doi:10.1046/j.1365-2567.1996.d01-749.x

101. Sindhava V, Woodman ME, Stevenson B, Bondada S. Interleukin-10 mediated autoregulation of murine B-1 B-cells and its role in Borrelia hermsii infection. PLoS One (2010) 5:e11445. doi:10.1371/journal.pone.0011445

102. Agrawal S, Gupta S. TLR1/2, TLR7, and TLR9 signals directly activate human peripheral blood naive and memory B cell subsets to produce cytokines, chemokines, and hematopoietic growth factors. JClin Immunol (2011) 31:89-98. doi:10.1007/s10875-010-9456-8

103. Silva-Barrios S, Smans M, Duerr CU, Qureshi ST, Fritz JH, Descoteaux A, et al. Innate immune B cell activation by Leishmania donovani exacerbates disease and mediates hypergammaglobulinemia. Cell Rep (2016) 15:2427-37. doi:10.1016/j.celrep.2016.05.028

104. Ng LG, Ng C-H, Woehl B, Sutherland APR, Huo J, Xu S, et al. BAFF costimulation of toll-like receptor-activated B-1 cells. Eur J Immunol (2006) 36:1837-46. doi:10.1002/eji.200635956

105. Bekeredjian-Ding I, Jego G. Toll-like receptors - sentries in the B-cell response. Immunology (2009) 128:311-23. doi:10.1111/j.1365-2567.2009.03173.x

106. Bialecki E, Paget C, Fontaine J, Capron M, Trottein F, Faveeuw C. Role of marginal zone B lymphocytes in invariant NKT cell activation. J Immunol (2009) 182:6105-13. doi:10.4049/jimmunol.0802273

107. Rubtsov AV, Swanson CL, Troy S, Strauch P, Pelanda R, Torres RM. TLR agonists promote marginal zone $\mathrm{B}$ cell activation and facilitate T-dependent IgM responses. J Immunol (2008) 180:3882-8. doi:10.4049/jimmunol.180. 6.3882

108. Durand CA, Hartvigsen K, Fogelstrand L, Kim S, Iritani S, Vanhaesebroeck B, et al. Phosphoinositide 3-kinase p110 delta regulates natural antibody production, marginal zone and B-1 B cell function, and autoantibody responses. J Immunol (2009) 183:5673-84. doi:10.4049/jimmunol.0900432

109. Figgett WA, Fairfax K, Vincent FB, Le Page MA, Katik I, Deliyanti D, et al. The TACI receptor regulates T-cell-independent marginal zone B cell responses through innate activation-induced cell death. Immunity (2013) 39:573-83. doi:10.1016/j.immuni.2013.05.019

110. Weller S, Bonnet M, Delagreverie H, Israel L, Chrabieh M, Maródi L, et al. IgM+IgD+CD27+ B cells are markedly reduced in IRAK-4-, MyD88-, and TIRAP- but not UNC-93B-deficient patients. Blood (2012) 120:4992-5001. doi:10.1182/blood-2012-07-440776

111. Rauch PJ, Chudnovskiy A, Robbins CS, Weber GF, Etzrodt M, Hilgendorf I, et al. Innate response activator B cells protect against microbial sepsis. Science (2012) 335:597-601. doi:10.1126/science.1215173

112. Weber GF, Chousterman BG, Hilgendorf I, Robbins CS, Theurl I, Gerhardt LMS, et al. Pleural innate response activator B cells protect against pneumonia via a GM-CSF-IgM axis. J Exp Med (2014) 211:1243-56. doi:10.1084/jem.20131471

113. Chiappini N, Cantisani R, Pancotto L, Ruggiero P, Rosa D, Manetti A, et al. Innate response activator (IRA) B cells reside in human tonsils and internalize bacteria in vitro. PLoS One (2015) 10:e0129879. doi:10.1371/ journal.pone.0129879

114. Walker JA, Barlow JL, McKenzie ANJ. Innate lymphoid cells - how did we miss them? Nat Rev Immunol (2013) 13:75-87. doi:10.1038/nri3349

115. Sonnenberg GF, Mjösberg J, Spits H, Artis D. Snapshot: innate lymphoid cells. Immunity (2013) 39:622.e-622.e. doi:10.1016/j.immuni.2013.08.021

116. Sonnenberg GF, Artis D. Innate lymphoid cells in the initiation, regulation and resolution of inflammation. Nat Med (2015) 21:698-708. doi:10.1038/ nm.3892

117. Cording S, Medvedovic J, Aychek T, Eberl G. Innate lymphoid cells in defense, immunopathology and immunotherapy. Nat Immunol (2016) 17:755-7. doi: $10.1038 /$ ni. 3448

118. Spits H, Artis D, Colonna M, Diefenbach A, Di Santo JP, Eberl G, et al. Innate lymphoid cells - a proposal for uniform nomenclature. Nat Rev Immunol (2013) 13:145-9. doi:10.1038/nri3365

119. Abt MC, Lewis $B B$, Caballero $S$, Xiong $H$, Carter RA, Sušac $B$, et al. Innate immune defenses mediated by two ILC subsets are critical for protection against acute Clostridium difficile infection. Cell Host Microbe (2015) 18:27-37. doi:10.1016/j.chom.2015.06.011

120. Sanos SL, Bui VL, Mortha A, Oberle K, Heners C, Johner C, et al. RORgammat and commensal microflora are required for the differentiation of mucosal interleukin 22-producing NKp46+ cells. Nat Immunol (2009) 10:83-91. doi:10.1038/ni.1684

121. Sonnenberg GF, Monticelli LA, Alenghat T, Fung TC, Hutnick NA, Kunisawa J, et al. Innate lymphoid cells promote anatomical containment of lymphoid-resident commensal bacteria. Science (2012) 336:1321-5. doi:10.1126/science. 1222551

122. Klose CSN, Flach M, Möhle L, Rogell L, Hoyler T, Ebert K, et al. Differentiation of type 1 ILCs from a common progenitor to all helper-like innate lymphoid cell lineages. Cell (2014) 157:340-56. doi:10.1016/j.cell.2014.03.030

123. Gladiator A, Wangler N, Trautwein-Weidner K, LeibundGut-Landmann S. Cutting edge: IL-17-secreting innate lymphoid cells are essential for host defense against fungal infection. J Immunol (2013) 190:521-5. doi:10.4049/ jimmunol.1202924

124. Moro K, Yamada T, Tanabe M, Takeuchi T, Ikawa T, Kawamoto H, et al. Innate production of $\mathrm{T}(\mathrm{H}) 2$ cytokines by adipose tissue-associated c-Kit $(+)$ Sca-1(+) lymphoid cells. Nature (2010) 463:540-4. doi:10.1038/nature08636

125. Neill DR, Wong SH, Bellosi A, Flynn RJ, Daly M, Langford TKA, et al. Nuocytes represent a new innate effector leukocyte that mediates type-2 immunity. Nature (2010) 464:1367-70. doi:10.1038/nature08900

126. Fuchs A, Vermi W, Lee JS, Lonardi S, Gilfillan S, Newberry RD, et al. Intraepithelial type 1 innate lymphoid cells are a unique subset of IL-12and IL-15-responsive IFN- $\gamma$-producing cells. Immunity (2013) 38:769-81. doi:10.1016/j.immuni.2013.02.010

127. Robinette ML, Fuchs A, Cortez VS, Lee JS, Wang Y, Durum SK, et al. Transcriptional programs define molecular characteristics of innate lymphoid cell classes and subsets. Nat Immunol (2015) 16:306-17. doi:10.1038/ ni.3094

128. Spits H, Bernink JH, Lanier L. NK cells and type 1 innate lymphoid cells: partners in host defense. Nat Immunol (2016) 17:758-64. doi:10.1038/ni.3482

129. Kiessling R, Klein E, Pross H, Wigzell H. "Natural" killer cells in the mouse. II. Cytotoxic cells with specificity for mouse Moloney leukemia cells. Characteristics of the killer cell. Eur J Immunol (1975) 5:117-21. doi:10.1002/ eji. 1830050209

130. Crellin NK, Trifari S, Kaplan CD, Cupedo T, Spits H. Human NKp44+IL-22+ cells and LTi-like cells constitute a stable RORC+ lineage distinct from conventional natural killer cells. J Exp Med (2010) 207:281-90. doi:10.1084/ jem.20091509

131. Bernink JH, Peters CP, Munneke M, Velde te AA, Meijer SL, Weijer K, et al. Human type 1 innate lymphoid cells accumulate in inflamed mucosal tissues. Nat Immunol (2013) 14:221-9. doi:10.1038/ni.2534

132. Geiger TL, Abt MC, Gasteiger G, Firth MA, O'Connor MH, Geary CD, et al. Nfil3 is crucial for development of innate lymphoid cells and host protection against intestinal pathogens. J Exp Med (2014) 211:1723-31. doi:10.1084/ jem.20140212

133. Fallon PG, Ballantyne SJ, Mangan NE, Barlow JL, Dasvarma A, Hewett DR, et al. Identification of an interleukin (IL)-25-dependent cell population that provides IL-4, IL-5, and IL-13 at the onset of helminth expulsion. J Exp Med (2006) 203:1105-16. doi:10.1084/jem.20051615 
134. Mjösberg JM, Trifari S, Crellin NK, Peters CP, van Drunen CM, Piet B, et al. Human IL-25- and IL-33-responsive type 2 innate lymphoid cells are defined by expression of CRTH2 and CD161. Nat Immunol (2011) 12:1055-62. doi:10.1038/ni.2104

135. Fort MM, Cheung J, Yen D, Li J, Zurawski SM, Lo S, et al. IL-25 induces IL-4, IL-5, and IL-13 and Th2-associated pathologies in vivo. Immunity (2001) 15:985-95. doi:10.1016/S1074-7613(01)00243-6

136. Hurst SD, Muchamuel T, Gorman DM, Gilbert JM, Clifford T, Kwan S, et al. New IL-17 family members promote Th1 or Th2 responses in the lung: in vivo function of the novel cytokine IL-25. J Immunol (2002) 169:443-53. doi:10.4049/jimmunol.169.1.443

137. Bostick JW, Zhou L. Innate lymphoid cells in intestinal immunity and inflammation. Cell Mol Life Sci (2016) 73:237-52. doi:10.1007/s00018-0152055-3

138. Spencer SP, Wilhelm C, Yang Q, Hall JA, Bouladoux N, Boyd A, et al. Adaptation of innate lymphoid cells to a micronutrient deficiency promotes type 2 barrier immunity. Science (2014) 343:432-7. doi:10.1126/ science. 1247606

139. Luci C, Reynders A, Ivanov II, Cognet C, Chiche L, Chasson L, et al. Influence of the transcription factor RORgammat on the development of NKp46+ cell populations in gut and skin. Nat Immunol (2009) 10:75-82. doi:10.1038/ ni. 1681

140. Satoh-Takayama N, Vosshenrich CAJ, Lesjean-Pottier S, Sawa S, Lochner M, Rattis F, et al. Microbial flora drives interleukin 22 production in intestinal $\mathrm{NKp} 46+$ cells that provide innate mucosal immune defense. Immunity (2008) 29:958-70. doi:10.1016/j.immuni.2008.11.001

141. Mortha A, Chudnovskiy A, Hashimoto D, Bogunovic M, Spencer SP, Belkaid Y, et al. Microbiota-dependent crosstalk between macrophages and ILC3 promotes intestinal homeostasis. Science (2014) 343:1249288-1249288. doi:10.1126/science. 1249288

142. Crellin NK, Trifari S, Kaplan CD, Satoh-Takayama N, Di Santo JP, Spits H. Regulation of cytokine secretion in human CD127(+) LTi-like innate lymphoid cells by Toll-like receptor 2. Immunity (2010) 33:752-64. doi:10.1016/j. immuni.2010.10.012

143. Ibiza S, García-Cassani B, Ribeiro H, Carvalho T, Almeida L, Marques R, et al. Glial-cell-derived neuroregulators control type 3 innate lymphoid cells and gut defence. Nature (2016) 535:440-3. doi:10.1038/nature18644

144. Sawa S, Lochner M, Satoh-Takayama N, Dulauroy S, Bérard M, Kleinschek $\mathrm{M}$, et al. ROR $\gamma \mathrm{t}+$ innate lymphoid cells regulate intestinal homeostasis by integrating negative signals from the symbiotic microbiota. Nat Immunol (2011) 12:320-6. doi:10.1038/ni.2002

145. Lee JS, Cella M, McDonald KG, Garlanda C, Kennedy GD, Nukaya M, et al. AHR drives the development of gut ILC22 cells and postnatal lymphoid tissues via pathways dependent on and independent of Notch. Nat Immunol (2012) 13:144-51. doi:10.1038/ni.2187

146. Zheng Y, Valdez PA, Danilenko DM, Hu Y, Sa SM, Gong Q, et al. Interleukin-22 mediates early host defense against attaching and effacing bacterial pathogens. Nat Med (2008) 14:282-9. doi:10.1038/nm1720

147. Sonnenberg GF, Nair MG, Kirn TJ, Zaph C, Fouser LA, Artis D. Pathological versus protective functions of IL-22 in airway inflammation are regulated by IL-17A. J Exp Med (2010) 207:1293-305. doi:10.1084/jem.20092054

148. Deshmukh HS, Liu Y, Menkiti OR, Mei J, Dai N, O’Leary CE, et al. The microbiota regulates neutrophil homeostasis and host resistance to Escherichia coli K1 sepsis in neonatal mice. Nat Med (2014) 20:524-30. doi:10.1038/nm.3542

149. Klose CSN, Kiss EA, Schwierzeck V, Ebert K, Hoyler T, d'Hargues Y, et al. A T-bet gradient controls the fate and function of CCR6-ROR $\gamma t+$ innate lymphoid cells. Nature (2013) 494:261-5. doi:10.1038/nature11813

150. Buonocore S, Ahern PP, Uhlig HH, Ivanov II, Littman DR, Maloy KJ, et al. Innate lymphoid cells drive interleukin-23-dependent innate intestinal pathology. Nature (2010) 464:1371-5. doi:10.1038/nature08949

151. Van Maele L, Carnoy C, Cayet D, Ivanov S, Porte R, Deruy E, et al. Activation of Type 3 innate lymphoid cells and interleukin 22 secretion in the lungs during Streptococcus pneumoniae infection. J Infect Dis (2014) 210:493-503. doi:10.1093/infdis/jiu106

152. Mebius RE, Streeter PR, Michie S, Butcher EC, Weissman IL. A developmental switch in lymphocyte homing receptor and endothelial vascular addressin expression regulates lymphocyte homing and permits CD4+ CD3- cells to colonize lymph nodes. Proc Natl Acad Sci U S A (1996) 93:11019-24. doi:10.1073/pnas.93.20.11019
153. Mebius RE, Rennert P, Weissman IL. Developing lymph nodes collect CD4+CD3- LTbeta+ cells that can differentiate to APC, NK cells, and follicular cells but not T or B cells. Immunity (1997) 7:493-504. doi:10.1016/ S1074-7613(00)80371-4

154. Takatori H, Kanno Y, Watford WT, Tato CM, Weiss G, Ivanov II, et al. Lymphoid tissue inducer-like cells are an innate source of IL-17 and IL-22. J Exp Med (2009) 206:35-41. doi:10.1084/jem.20072713

155. Sonnenberg GF, Monticelli LA, Elloso MM, Fouser LA, Artis D. CD4(+) lymphoid tissue-inducer cells promote innate immunity in the gut. Immunity (2011) 34:122-34. doi:10.1016/j.immuni.2010.12.009

156. Marafini I, Monteleone I, Di Fusco D, Cupi ML, Paoluzi OA, Colantoni A, et al. TNF- $\alpha$ producing innate lymphoid cells (ILCs) are increased in active celiac disease and contribute to promote intestinal atrophy in mice. PLoS One (2015) 10:e0126291. doi:10.1371/journal.pone.0126291

157. Wilhelm C, Hirota K, Stieglitz B, Van Snick J, Tolaini M, Lahl K, et al. An IL-9 fate reporter demonstrates the induction of an innate IL-9 response in lung inflammation. Nat Immunol (2011) 12:1071-7. doi:10.1038/ni.2133

158. Esin S, Batoni G, Counoupas C, Stringaro A, Brancatisano FL, Colone M, et al. Direct binding of human NK cell natural cytotoxicity receptor NKp44 to the surfaces of Mycobacteria and other bacteria. Infect Immun (2008) 76:1719-27. doi:10.1128/IAI.00870-07

159. Chaushu S, Wilensky A, Gur C, Shapira L, Elboim M, Halftek G, et al. Direct recognition of Fusobacterium nucleatum by the NK cell natural cytotoxicity receptor NKp46 aggravates periodontal disease. PLoS Pathog (2012) 8:e1002601. doi:10.1371/journal.ppat.1002601

160. McElroy DS, Ashley TJ, DŁOrazio SEF. Lymphocytes serve as a reservoir for Listeria monocytogenes growth during infection of mice. Microb Pathog (2009) 46:214-21. doi:10.1016/j.micpath.2009.01.003

161. Salgado-Pabon W, Celli S, Arena ET, Nothelfer K, Roux P, Sellge G, et al. Shigella impairs T lymphocyte dynamics in vivo. Proc Natl Acad Sci U S A (2013) 110:4458-63. doi:10.1073/pnas.1300981110

162. Telford JL, Baldari CT. Shigella targets T cells. Cell Host Microbe (2011) 9:253-4. doi:10.1016/j.chom.2011.04.003

163. Konradt C, Frigimelica E, Nothelfer K, Puhar A, Salgado-Pabon W, Di Bartolo V, et al. The Shigella flexneri type three secretion system effector IpgD inhibits $\mathrm{T}$ cell migration by manipulating host phosphoinositide metabolism. Cell Host Microbe (2011) 9:263-72. doi:10.1016/j.chom.2011. 03.010

164. Zarember KA, Godowski PJ. Tissue expression of human toll-like receptors and differential regulation of toll-like receptor mRNAs in leukocytes in response to microbes, their products, and cytokines. JImmunol (2002) 168:554-61. doi:10.4049/jimmunol.168.2.554

165. Hornung V, Rothenfusser S, Britsch S, Krug A, Jahrsdörfer B, Giese T, et al. Quantitative expression of toll-like receptor 1-10 mRNA in cellular subsets of human peripheral blood mononuclear cells and sensitivity to CpG oligodeoxynucleotides. J Immunol (2002) 168:4531-7. doi:10.4049/ jimmunol.168.9.4531

166. Gelman AE, Zhang J, Choi Y, Turka LA. Toll-like receptor ligands directly promote activated CD4+ T cell survival. J Immunol (2004) 172:6065-73. doi:10.4049/jimmunol.172.10.6065

167. Imanishi T, Hara H, Suzuki S, Suzuki N, Akira S, Saito T. Cutting edge: TLR2 directly triggers Th1 effector functions. J Immunol (2007) 178:6715-9. doi:10.4049/jimmunol.178.11.6715

168. Biswas A, Banerjee P, Biswas T. Porin of Shigella dysenteriae directly promotes toll-like receptor 2-mediated CD4+ T cell survival and effector function. Mol Immunol (2009) 46:3076-85. doi:10.1016/j.molimm.2009.06.006

169. Komai-Koma M, Jones L, Ogg GS, Xu D, Liew FY. TLR2 is expressed on activated T cells as a costimulatory receptor. Proc Natl Acad Sci U S A (2004) 101:3029-34. doi:10.1073/pnas.0400171101

170. Nyirenda MH, Sanvito L, Darlington PJ, O'Brien K, Zhang G-X, Constantinescu CS, et al. TLR2 stimulation drives human naive and effector regulatory $\mathrm{T}$ cells into a Th17-like phenotype with reduced suppressive function. J Immunol (2011) 187:2278-90. doi:10.4049/jimmunol.1003715

171. Bendigs S, Salzer U, Lipford GB, Wagner H, Heeg K. CpGoligodeoxynucleotides co-stimulate primary $\mathrm{T}$ cells in the absence of antigen-presenting cells. Eur J Immunol (1999) 29:1209-18. doi:10.1002/ (SICI)1521-4141(199904)29:04<1209::AID-IMMU1209>3.0.CO;2-J

172. Zheng L, Asprodites N, Keene AH, Rodriguez P, Brown KD, Davila E. TLR9 engagement on $\mathrm{CD} 4 \mathrm{~T}$ lymphocytes represses gamma-radiation-induced 
apoptosis through activation of checkpoint kinase response elements. Blood (2008) 111:2704-13. doi:10.1182/blood-2007-07-104141

173. Funderburg N, Luciano AA, Jiang W, Rodriguez B, Sieg SF, Lederman MM. Toll-like receptor ligands induce human $\mathrm{T}$ cell activation and death, a model for HIV pathogenesis. PLoS One (2008) 3:e1915. doi:10.1371/journal. pone. 0001915

174. Crellin NK, Garcia RV, Hadisfar O, Allan SE, Steiner TS, Levings MK. Human CD4+ T cells express TLR5 and its ligand flagellin enhances the suppressive capacity and expression of FOXP3 in CD4+CD25+ T regulatory cells. J Immunol (2005) 175:8051-9. doi:10.4049/jimmunol.175.12.8051

175. Caron G, Duluc D, Frémaux I, Jeannin P, David C, Gascan H, et al. Direct stimulation of human T cells via TLR5 and TLR7/8: flagellin and R-848 up-regulate proliferation and IFN-gamma production by memory CD4+ T cells. J Immunol (2005) 175:1551-7. doi:10.4049/jimmunol.175. 3.1551

176. Dominguez-Villar M, Gautron A-S, de Marcken M, Keller MJ, Hafler DA. TLR7 induces anergy in human CD4(+) T cells. Nat Immunol (2015) 16:118-28. doi:10.1038/ni.3036

177. Steele S, Radlinski L, Taft-Benz S, Brunton J, Kawula TH. Trogocytosisassociated cell to cell spread of intracellular bacterial pathogens. Elife (2016) 5:e1000211-3. doi:10.7554/eLife.10625
178. Izquierdo-Useros N, Naranjo-Gómez M, Erkizia I, Puertas MC, Borràs FE, Blanco J, et al. HIV and mature dendritic cells: trojan exosomes riding the trojan horse? PLoS Pathog (2010) 6:e1000740. doi:10.1371/journal. ppat.1000740.g004

179. Lanzavecchia A, Roosnek E, Gregory T, Berman P, Abrignani S. T cells can present antigens such as HIV gp120 targeted to their own surface molecules. Nature (1988) 334:530-2. doi:10.1038/334530a0

180. Barnaba V, Watts C, de Boer M, Lane P, Lanzavecchia A. Professional presentation of antigen by activated human T cells. Eur J Immunol (1994) 24:71-5. doi:10.1002/eji.1830240112

Conflict of Interest Statement: The authors declare that the research was conducted in the absence of any commercial or financial relationships that could be construed as a potential conflict of interest.

Copyright (c) 2016 Cruz-Adalia and Veiga. This is an open-access article distributed under the terms of the Creative Commons Attribution License (CC BY). The use, distribution or reproduction in other forums is permitted, provided the original author(s) or licensor are credited and that the original publication in this journal is cited, in accordance with accepted academic practice. No use, distribution or reproduction is permitted which does not comply with these terms. 